\title{
The Economic Effects of the Protestant Reformation: Testing the Weber Hypothesis in the German Lands
}

\author{
Davide Cantoni* \\ Universitat Pompeu Fabra
}

2 December 2010

\begin{abstract}
Many theories, most famously Max Weber's essay on the "Protestant ethic," have hypothesized that Protestantism should have favored economic development. With their considerable religious heterogeneity and stability of denominational affiliations until the 19th century, the German Lands of the Holy Roman Empire present an ideal testing ground for this hypothesis. Using population figures in a dataset comprising 272 cities in the years 1300-1900, I find no effects of Protestantism on economic growth. The finding is robust to the inclusion of a variety of controls, and does not appear to depend on data selection or small sample size. In addition, Protestantism has no effect when interacted with other likely determinants of economic development. I also analyze the endogeneity of religious choice; instrumental variables estimates of the effects of Protestantism are similar to the OLS results.
\end{abstract}

Version: 2.7 .1

Keywords: Protestantism, Culture, Economic Growth, Historical Development, Germany

JEL Classification: N13, N33, O11, Z12

\footnotetext{
* Departament d'Economia i Empresa, Universitat Pompeu Fabra, Ramon Trias Fargas 25-27, 08005 Barcelona (Spain). Email: cantoni@fas.harvard.edu. I thank Daron Acemoglu, Regina Baar-Cantoni, Robert Barro, Jeremiah Dittmar, Camilo Garcia-Jimeno, Claudia Goldin, Tim Guinnane, Martin Hellwig, Elhanan Helpman, James Robinson, Holger Spamann, Eike Wolgast and Noam Yuchtman for helpful comments and suggestions, as well as seminar audiences at Bocconi, Brown, the EEA Annual Meeting (Barcelona), IIES Stockholm, Harvard, MPI Bonn, Munich, UPF, and Yale. Financial support by the Economic History Association, the Minda de Gunzburg Center for European Studies and the Studienstiftung des Deutschen Volkes is gratefully acknowledged. Jessica Fronk, Eda Karesin and Niklas Neckel provided excellent research assistance.
} 


\section{Introduction}

What is the relationship between religious beliefs, with their impact on moral reasoning and the related behavioral incentives, and economic growth? This question has been a long-standing topic of research in the social sciences. Many observers have attributed the rise of England and the Netherlands in the 17th and 18th century, as opposed to the decline of Spain and Italy, to their Protestant faith (see Braudel 1982, p. 567). Indeed, Protestantism, with its emphasis on the believers' direct relationship with and responsibility toward God, seems intuitively conducive to a modern, individualistic and rational, view of mankind. As a consequence, several theories have been put forward as to how precisely Protestantism is supposed to affect economic growth, most famously by Max Weber in his essay about the Protestant Ethic (Weber, 1904/05). But in fact, few empirical studies have investigated the comparative performance of Catholics and Protestants over the long run.

The present paper exploits the history of early modern Germany to assess the causal link between Protestantism and economic growth. The "natural experiment" considered here-the forced imposition of religious denominations as a consequence of the Peace of Augsburg (1555) gave rise to substantial heterogeneity of religious denominations across the Holy Roman Empire and allows the investigation of differences in growth patterns across the Protestant and Catholic parts of the Empire. Using a dataset of cities and their population sizes, I find no positive effect of Protestantism on economic growth over the very long run (1300-1900); in fact, the performances of Catholic and Protestant cities and regions are virtually indistinguishable. Even the upper bounds of the confidence intervals around the estimated impact of Protestantism on city size would be suggestive of very small effects, approximately equal to one third of the standard deviation of city sizes in the dataset. These results are robust to a wide array of alternative specifications, and are confirmed by an instrumental variables strategy.

The empirical setting used here presents a series of advantages. First, the homogeneity of religious choice: almost all the territories analyzed were either entirely Protestant or entirely Catholic from the 16th century until at least the end of the Empire in 1806. Second, the exogeneity of reli- 
gious choice: an individual's religious denomination was not freely chosen, but was the result of the choice of the local ruler (prince, duke...) whether to join the new religion; this choice was imposed on the subjects according to the principle cuius regio, eius religio (whose realm, his religion). I will also investigate the exogeneity of the ruler's religious choice and discuss to what extent it can be considered orthogonal to his territory's latent characteristics. Last, as opposed to studies about religious minorities and their economic success (e.g., the Huguenots), religious choices in early modern Germany affected the whole spectrum of the local population, and are therefore more indicative of the net (causal) effect of Protestantism on economic activity.

The purpose of this paper is to analyze the long-term economic development of Protestant and Catholic regions over six centuries (1300-1900). The long time span considered allows to verify the presence of potential pre-existing trends and more generally to quantify the time-varying nature of the postulated treatment effects. The main dependent variable used is the size of cities, which arguably provides a good proxy for the level of economic development. Moreover, no other variable (real wages, body height, quality of housing...) among those commonly used in the analysis of historical trends of well-being is available with a comparable cross-sectional breadth and temporal frequency.

Figure 1 gives an intuitive impression of the relationship between choice of denomination and average city size. To control for pre-trends across groups before the actual onset of the Reformation, I classify a city as "Protestant" in the years before 1517 if it became Protestant by 1600. A broad pattern, which I will later substantiate through regression analysis, is evident from the graph: Protestant cities are not growing differently from Catholic cities in the period after the Reformation; if anything, differences in $(\log )$ city size become less evident over time. ${ }^{1}$

\section{[Figure 1 about here]}

Because of this temporal scope, I may not be able to test specific channels of causation to the extent that a single cross-section in time or survey data would allow to do. However, in addition to the sizes of cities and their religious affiliations that form the core of my dataset, I collect a wide

\footnotetext{
${ }^{1}$ Two other facts are notable in this graph, and will be discussed later: cities of the Protestant camp start off smaller in 1300, and are more severely hit by the Thirty Years' War (1618-1648), as evident from the decline between 1600 and 1700.
} 
variety of additional variables on city and territory characteristics from several sources: these variables comprise information about geographic characteristics, such as latitude, longitude, or presence of a navigable river; about institutional features, such as the date of incorporation, the prevalent inheritance rule, or the secular vs. ecclesiastical nature of government; and about economic characteristics, such as the payment of taxes, the number of monasteries etc. With these variables, I can assess the impact of a series of confounding factors and shed light on the extent to which the effects of Protestantism are heterogeneous across cities; the potential presence of such heterogeneities can suggest the prevalence of certain channels of transmission. Finally, I try to disentangle the causality nexus between Protestantism and economic success with an instrumental variables strategy.

There are several strands of research related to this paper. First, there are cross-country studies relating Protestantism to economic outcomes in a variety of countries, such as Grier (1997), Delacroix and Nielsen (2001), and Barro and McCleary (2003). My work expands on this by examining the same relationship within a well-defined, culturally homogeneous setting, and by considering the endogeneity of religious choice. Second, this paper belongs to the broader literature about cultural economics, see e.g. Guiso et al. (2006). It contributes to this strand of research by estimating the impact of a notable cultural factor in a historical context (relatedly, Tabellini 2009 also analyzes the relationship between cultural traits and long-run development across European regions).

Finally, this paper expands on existing work on the economic differences between Protestants and Catholics in the specific context of Germany, an analysis begun by Offenbacher (1900)—whose studies provided the empirical observations Weber based his theory on-and most recently continued by Becker and Wößmann (2009). Relative to the latter paper, my project differs along a series of dimensions: the setting (cities in the Holy Roman Empire vs. counties, urban and rural, in Prussia), the time period analyzed (the evolution 1300-1900 vs. a cross-section in 1871), and the outcome considered (urban growth vs. income levels, or share of the population in manufacturing). It is, in particular, the first aspect (location) that explains why Becker and Wößmann find a positive effect of Protestantism on economic development: in a predominantly rural setting, dif- 
ferences in literacy (induced by religious choice) can matter in the dissemination of the second industrial revolution (on this, also see Becker et al., 2011). In contrast, my findings suggest that in an urban setting - the setting where we are most likely to expect religious choice to exert impulses on the commercial and entrepreneurial spirit in the pre-industrial age-Protestantism has no power to explain differentials in economic growth.

In the following section, I expose the arguments that have been proposed to link Protestantism with economic progress, and give an introduction to the historical events in the German lands of the Holy Roman Empire covered by my analysis. In section 3, I introduce the data used in this project and discuss the use of city sizes as a proxy variable. Econometric evidence on differences between Catholic and Protestant parts of Germany is provided in section 4. In section 5, I discuss the endogeneity of religious choice and how this affects the main empirical results, while section 6 tests a series of more differentiated hypotheses about the potential channels of transmission that link religious faith with economic growth. The last section discusses a series of explanations for the main findings and concludes the paper.

\section{Historical background}

\subsection{Protestantism and economic growth: A classic hypothesis}

Since the seminal work by Max Weber, various theories about the relationship between Protestantism and economic development have been proposed and discussed. Understanding through which channels Protestantism could possibly affect economic growth will help in formulating hypotheses about where and when to find its potential effects: a specific causal link might only be relevant at a certain point in time, or be valid only for a certain subset of cities.

Weber's theory was motivated by the observation that in Baden (a state of southwest Germany) Protestants earned more than Catholics, and were more likely to attend technical rather than liberal arts schools. While Protestants in Baden were mostly Lutheran, most of Weber's theory revolves around Calvinism and ascetic branches of Christianity. He hypothesized that-through 
the doctrine of predestination-Calvinism, and the Puritan sects in particular, were successful in instilling the view that work and money-making should be seen as a vocation, an end in itself. Weber argued that this attitude was central to the initial development of modern capitalism, but also that this role of religious views would not be necessary any more in a successfully industrialized society (Weber, 1904/05, ch. 2). ${ }^{2}$

In fact, other scholars of religious doctrines have also pointed out how Calvinism, emerging in a bourgeois and urban society, was particularly favorable to the instances of business life. Troeltsch (1931, p. 644) points out Calvinists' "industrious habits, detachment from the world, and rational and utilitarian spirit," which promoted the dedication to commercial activities and the accumulation of capital. Relatedly, attitudes toward usury laws and the charging of interest have been proposed as an important channel: Calvin approved of lending money against interest in business matters (Letter on Usury, 1545), whereas the Catholic church reasserted the prohibition of usury in the bull Vix pervenit as late as 1745 (Hauser, 1927). According to these theories, one should expect positive effects of Protestantism on economic growth in Calvinist cities, and in particular in those cities with a potential for trade and commercial activity.

In the territories of the Holy Roman Empire studied in this paper, however, Lutheranism was the dominant branch of Protestantism. Ernst Troeltsch (1931, pp. 554-576) discusses the Lutheran stance towards economic questions. While Luther was generally more conservative in his economic ethic than Calvin — for instance, being opposed to interest on money lending — the doctrines of Lutheranism still had momentous economic consequences: the abolition of monastic orders, of mendicancy, the reduction of Church holidays, and the secularization of church holdings all released large amounts of labor and capital and arguably increased output. Furthermore,

[...] the control of the Church in the sphere of economics was removed, which had brought questions like the fixing of a just price, and of usury, before the judgment seat of the confessional. All matters of that kind were now handed over to the secular authority entirely, and to Natural Law. [...] The modern tendency of the Reformers consists essentially in handing over economic matters to the territorial lords, who are obliged and entitled to increase possessions and industry for the good of the whole [...] Thus with the blessings of Lutheranism and without ecclesiastical

\footnotetext{
${ }^{2}$ Weber's seminal essay has been discussed widely since its publication. Among the innumerable rebuttals, I will only cite Brentano (1916), Tawney (1926), Robertson (1933), and Samuelsson (1961).
} 
control they entered the path of mercantilism as well as that of an absolutist social policy.

(Troeltsch, 1931, p. 554 and fn. 272)

Thus we should expect Lutheranism to increase economic activity, especially where large Church holdings are dissolved, and to promote the emergence of modern absolutist states, which in turn could have positive economic effects if centralized states are in fact the superior institutional setup of the modern era.

Other researchers have downplayed the importance of Protestantism's economic teachings, while pointing out how other elements of the Protestant religions might have fostered growthpromoting attitudes. Merton (1938) discusses how some branches of Protestantism, such as the English Puritans and the German Pietists, might have favored the rise of modern Western science. Hill (1961) also considers the actual economic teachings of Luther and Calvin marginal, and points out instead how Protestantism, by stressing individual freedom and responsibility toward God, dispensed with the Church hierarchy and thus encouraged Protestants to become more flexible and open toward new ideas. If these theories are correct, Protestantism should have favored economic growth especially in the period after the Scientific and the Industrial Revolutions.

More recently, many economists have studied the importance of trust, on the assumption that trust is a fundamental element allowing for the establishment of market exchange. Building on Putnam (1993), who claimed that hierarchical religions such as Catholicism discourage "horizontal" ties between people and hence the formation of trust, La Porta et al. (1997) show that countries with hierarchical religions perform comparatively worse on a wide range of contemporary outcomes, relating to government efficiency, civic participation, the quality of social infrastructure, and the formation of large corporations. This relationship is further examined by Guiso et al. (2003) using data from the World Values Survey: compared to Catholics, Protestants are found to be significantly more likely to trust strangers, less likely to cheat on taxes and to accept a bribe. Catholics are, perhaps surprisingly, more likely to teach thrift to their children, and to have a positive view of competition. ${ }^{3}$ These findings also suggest a beneficial effect of Protestantism, especially in an

\footnotetext{
${ }^{3}$ Relatedly, Blum and Dudley (2001) propose a link based on network externalities; they suggest that Protestants are less likely to defect in a game with repeated interactions (because of the absence of easy mechanisms of penance), which in turn favors the establishment of trade networks.
} 
urban and commercial setting.

Finally, Becker and Wößmann (2009) have suggested a human-capital based theory of Protestant advantage. They argue that the differences in economic outcomes between Catholics and Protestants in Prussia around 1871 can be fully explained by differences in literacy. These differences trace back to Luther's exhortation to be able to read and interpret the Bible on one's own, which through the establishment of elementary schools led to the accumulation of human capital both in cities and in the countryside all over Protestant territories. If literacy is important for the development of an industrial economy, but is less productivity-enhancing in the agricultural sector, we should expect the Protestants' accumulation of human capital to exert positive effects particularly during the 19 th century. ${ }^{4}$

\subsection{Historical background: Protestantism in Early Modern Germany}

The political and religious situation in Germany at the time of the Reformation was peculiar within the European context and is crucial for my empirical strategy to identify the economic effects of the Protestant Reformation. There were three different phases of the spread of Protestantism across the German lands (until 1555; 1555-1624; after 1624); these phases are distinguished by the different legal context determining religious choice. ${ }^{5}$

Institutions and actors. The territory of the Holy Roman Empire occupied mainly the presentday central European states of Germany, Austria, Belgium, Luxembourg, the Czech Republic, Switzerland, and parts of France and Poland. The Emperor was an elected sovereign, chosen by seven princes of the Empire (the Electors). ${ }^{6}$ He wielded less power than other contemporary rulers, such as the King of France or the King of England. Rather, most of the attributes that would

\footnotetext{
${ }^{4}$ This relationship has also been put forward by Sandberg (1979) to explain Sweden's long-run growth performance. While a classic view downplayed the importance of human capital during the British industrial revolution (see Mitch 1999), Becker et al. (2011) argue that in the case of Prussia pre-existing levels of schooling substantially accelerated industrialization in the 19th century.

${ }^{5}$ This historical summary is based largely on Schilling (1988). Good English-language introductions to the Reformation in Germany are provided by Scribner (1994) and Dixon (2002).

${ }^{6}$ These were the prince-bishops of Cologne, Mainz, and Trier; as well as the King of Bohemia and the Electors of Brandenburg, Saxony, and the Palatinate.
} 
be considered essential components of sovereignty were exercised by the princes of the Empire. ${ }^{7}$ There were hundreds of territories ruled by princes, dukes, counts, or Church dignitaries, such as prince-bishops; all of these were sovereign entities but for the largely nominal primacy of the Emperor. Some cities were "Free Imperial cities," being directly subjected only to the suzerainty of the Emperor. Most of the other cities were located in one of the territorial lords' territories and hence were subject to his jurisdiction, while still enjoying some degree of self-government.

The Catholic Church was an important actor in this context, owing both to its (up to then) mostly unchallenged spiritual leadership and its occasional temporal powers. Whereas in other countries the monarchs had already undertaken steps towards a national church, ensuring the rights to nominate bishops, ${ }^{8}$ in Germany the Catholic Church was able to capitalize on the states' weakness and maintain a wide array of privileges.

Beginning of the Reformation. The sale of indulgences by the Church prompted Martin Luther, a hitherto unknown Augustinian monk and lecturer at the University of Wittenberg, to express his objections to this practice in 95 theses on October 31, 1517. He was not the first one to protest against these practices; however, he could count on a series of fortunate circumstances which would warrant success to his endeavor, thanks to the power struggles between the Emperor, the Pope, and the territorial lords on the one hand, and to the contemporary intellectual networks and technological breakthroughs (Gutenberg's printing press) on the other hand. ${ }^{9}$ At first, many, including the Pope, dismissed his action as an uninfluential protest without consequences. Luther's pamphlets could spread rapidly and be translated in multiple languages.

The first groups who seemed ready to accept the new teachings were peasants, knights, and the urban populations. While the insurgencies of the first two groups were ultimately repressed in 1522-25, Protestantism continued to exert a major attraction on the inhabitants of the cities, both in Free Imperial cities and in cities subject to the jurisdiction of a territorial lord. Widespread

\footnotetext{
${ }^{7}$ While in states like England and France the king was able to impose his supremacy over local lords in the late Middle Ages, in the Holy Roman Empire the opposite turned out to be true: regional lords gained power at the expense of the Emperor (North and Thomas, 1973, pp. 79-86).

${ }^{8}$ In the case of France, this occurred through the Concordat of Bologna in 1516.

${ }^{9}$ One more fortunate circumstance, the ongoing fight against the Turks in Austria, has recently been quantitatively analyzed by Iyigun (2008).
} 
literacy, the presence of humanist circles, universities, and printing presses, or the ideology of freedom intrinsic to the nature of the city are among the reasons for this phenomenon. By the end of the 1520s the vast majority of Free Imperial cities had become Protestant. Many of the cities on princely territories had also started to replace Catholic priests with Lutheran preachers, thereby putting pressure on their territorial lords who had not yet formally introduced the new faith. ${ }^{10}$

The princes of the Empire were more cautious in joining the bandwagon of Protestantism. They had to balance various factors: on the one hand, the Estates representing the cities and the minor nobility would often push in favor of adopting the new faith. On the other hand, there was the desire not to unsettle the delicate balance of power between princes, Emperor, and the Church. In that first period, it was not clear whether and how the princes had the right to change the fundamentals of faith in their territories, or even to seize the Church's holdings.

The first green light toward the formal introduction of the Reformation was given at the First Diet of Speyer in 1526, ${ }^{11}$ when a new formula was coined: princes should behave in religious matters "as they may hope and trust to answer before God and his imperial Majesty" until the meeting of a general council of the Church. As the general council envisaged by the parties involved failed to materialize, this formula became in practice the laissez-passer for the official introduction of Reformation and of separate state churches in German territories.

Peace of Augsburg (1555). In the late 1540s, an attempt undertaken by Emperor Charles V to restore his authority and the Catholic faith proved short-lived. At the Imperial Diet of Augsburg in 1555, the Emperor accepted a peace treaty which included the formula known as cuius regio, eius religio: it gave princes the right to impose their preferred denomination upon their subjects. This policy ended 38 years of legal limbo (1517-1555), in which uncertainty had reigned as to whether princes were allowed to introduce the Reformation. Furthermore, it guaranteed 60 years of relative peace until the outbreak of the Thirty Years' War, and sanctioned the primacy of the princes over the Emperor in religious matters. Several more territories converted formally to Protestantism in this period, including some prince-bishoprics.

\footnotetext{
${ }^{10}$ On this topic, see the seminal work by Moeller (1987), as well as Ozment (1975) and Dickens (1979).

${ }^{11}$ Imperial Diets were assemblies of all princes of the Empire which convened at irregular intervals.
} 
Peace of Westphalia (1648). The Thirty Years' War (1618-48) would hardly change the denominational split in the Empire, despite its huge toll of lost lives and destruction. The Peace of Westphalia in 1648 established retroactively January 1st, 1624 as the normal date: the denomination of a territory at that point in time would have to be maintained; the conversion of a prince to another faith would not entitle him any more to force his conversion upon his subjects. Some conversions of princes occurred in fact in subsequent years, mainly for political reasons; for example, the staunchly Lutheran kings of Saxony converted to Catholicism in the 18th century in the hope of obtaining the Polish crown. This choice had no effect on the citizens of Saxony, who did not see a Catholic church in their cities until well into the 19 th century. ${ }^{12}$ For the vast majority of the territories in Germany no more denominational changes took place after 1624.

In sum, this unique historical process guaranteed a remarkable degree of confessional homogeneity and continuity within territories or cities until the 19th century, when barriers to the free movement of peasants were finally removed. To show exemplarily how stable these patterns proved to be, Table 1 presents data from the (denominationally mixed) region of Westphalia, in northwest Germany. Using the results from the Prussian census of 1849, reorganized to match historical borders, the table shows how, even 50 years after the collapse of the Holy Roman Empire and after the beginnings of industrialization, most people still resided in denominationally homogeneous areas which reflected the arrangements set by the Peace of Westphalia.

[Table 1 about here]

\section{Data: City sizes and city characteristics}

Observing the evolution of city sizes provides us with arguably one of the best measures of economic development in pre-industrial times. Cities were the centers of learning, of political administration, and of economic activity. Books were printed in cities, artisans produced their tools and

\footnotetext{
${ }^{12}$ More difficult was the case of Protestant territories conquered in war or through dynastic succession by Catholic princes; most notably, this was the case of the (Rhenish) Palatinate, a Calvinist territory inherited by a Catholic line of the Wittelsbach family. In this case, it depended on the willingness of the institutions of the Empire (notably the Imperial Chamber Court, the Reichskammergericht) and the credibility of the other princes' threats whether the new ruler was successful in imposing his faith. In general, cities, with their degree of self-government, could avoid interferences, whereas the broad mass of people in the countryside might have been more easily converted.
} 
goods in cities, peasants came to cities to exchange their agricultural produce. In a Malthusian world in which population growth reacts to economic conditions, or in a model with unlimited supply of labor from the countryside, improvements in urban total factor productivity should be reflected in city sizes. ${ }^{13}$ Hence, if Protestantism did indeed increase the productivity of urban dwellers-by providing them with a peculiar "work ethic," by encouraging the accumulation of human capital, or by approving of modern commercial practices, for example- this should translate into larger city sizes.

\subsection{Dataset: variables, summary statistics, correlations}

To test the link between Protestantism and economic development, I use the population estimates by Bairoch et al. (1988) to construct a dataset encompassing 272 cities of the former Holy Roman Empire over six centuries-this compilation includes all cities that reached the threshold of 5000 or more inhabitants in or before 1800. ${ }^{14}$ The years considered in my panel are spaced in 100 years' intervals from 1300 to 1700, and then in fifty years' intervals from 1750 to 1850, as in Bairoch et al. (1988). In addition, I include city size data for the years 1875 and 1900, which are drawn from national statistics (Statistik des Deutschen Reiches for Germany; Statistisches Jahrbuch for Austria). The distribution of Catholic and Protestant cities in 1850 in my dataset is shown in Figure 2. As can be seen, Catholic cities generally cluster in the southeastern part of the Empire, Protestant ones in the northeast, whereas in the Western half of the Empire the picture is definitely mixed.

\section{[Figure 2 about here]}

Summary statistics of the variables in the dataset are reported in Table $2 .{ }^{15}$ The unconditional differences in means of city size show that Protestant cities start smaller than their Catholic counterparts in 1300, but later make up for this difference; this comparison, however, is problematic,

\footnotetext{
${ }^{13}$ See Bairoch $(1977,1988)$ and de Vries $(1984)$ on city size and economic development.

${ }^{14}$ In all tables, I present results based on the 272 cities that lay in the German-speaking parts of the Empire, thereby excluding 25 cities of the Empire which lay in Bohemia, Moravia, Carniola (Slovenia) and parts of Northern Italy. This is motivated by the desire to consider not only a homogeneous legal setting, but also a homogeneous cultural space, where the message of the Reformation could spread without the need for translation. All results are robust to inclusion of the other 25 cities.

${ }^{15}$ Full descriptions and sources for the data are given in Appendix A.1.
} 
due to the inclusion of additional cities as time progresses. The second and third panel of the table confirm that there are some substantial differences across the two subsamples. In terms of their geographic characteristics (second panel), Protestant cities are more likely to be in the north and in the east (higher latitude/longitude values); in terms of their social and historical features (third panel), Catholic cities appear to be older and with a stronger presence of the Church (more monasteries, more likely to lie in an ecclesiastical territory).

\section{[Table 2 about here]}

Correlations among the main variables are reported in Table 3, and reveal how older cities tend to lie in the south and the west of the Empire, and are more likely to be either free or ecclesiastical. Not surprisingly, older cities are larger at the beginning of the dataset (1300), and have a stronger church presence, as measured by the number of monasteries.

[Table 3 about here]

\subsection{City sizes as indicators of economic development}

City size data are uniquely suited to compare the relative performance of Catholic and Protestant regions of the Holy Roman Empire, both because of their cross-sectional breadth and because of the ability to observe changes over time. However, if we investigate the relationship between Protestantism and economic development, a more immediate ultimate outcome of interest would be real GDP (per capita), or a variable closely related to that.

To understand how city sizes relate to other indicators of economic development, I use the Prussian manufacturing census of the years 1816-1821, one of the earliest and most detailed comprehensive censuses of population and economic activity (Krug and Mützell, 1825), to compare city sizes with a variety of social and economic outcomes. ${ }^{16}$ The results from this census are relevant because they provide evidence on the relationship between city size and economic outcomes in an epoch recent enough to have high-quality statistical data, but early enough for the cities not to be affected yet by the Industrial Revolution.

\footnotetext{
${ }^{16}$ Detailed descriptions of the variables used are provided in Appendix A.2.
} 
The regressions of Table 4 show that city size is strongly correlated with educational outcomes, such as the teacher-to-student ratio in elementary schools; with accumulated capital, as embodied by the sums insured with the local fire insurance company; with indicators of economic activity, such as the tax on businesses; and with the quality of housing, as represented by the percentage of houses with stone walls (as opposed to timber) and with shingled roofs (as opposed to thatchered). City size is not clearly related, though, with any particular branch of economic activity, as emerges from the lack of correlation with the number of looms or merchants (columns (4) and (5)). As evident from panel B, these results also hold when the sample is limited to those Prussian cities that are featured in the Bairoch et al. (1988) dataset which I will use in this paper.

\section{[Table 4 about here]}

\section{City growth in Protestant and Catholic territories}

\subsection{Empirical framework and baseline results}

To capture differentials in city growth between Protestant and Catholic cities in a more rigorous fashion, I use a generalized differences-in-differences setup. The simplest conceivable regression equation relating the outcome of interest, city size $u_{i t}$, to denominational affiliation is the following:

$$
\ln \left(u_{i t}\right)=\chi_{i}+\chi_{t}+\alpha \cdot \text { Prot }_{i} \cdot{\text { Post } 1517_{t}+\varepsilon_{i t}}
$$

In this baseline differences-in-differences setup, I allow for a full set of city fixed effects $\left(\chi_{i}\right)$ and year fixed effects $\left(\chi_{t}\right)$. In addition to these, the interaction term between a city's religion, Prot $_{i}$, and an indicator for the time periods after the inception of the Reformation, Post $1517_{t}$, captures the effect of Protestantism on city size. ${ }^{17}$ The estimated coefficient $\alpha$ will reflect the average difference in log city size between Protestant and Catholic cities.

\footnotetext{
${ }^{17}$ As in the context of Figure 1, the variable Prot $_{i}$ is equal to one throughout 1300-1900 if the city became Protestant before the normal year 1624, and zero throughout if it remained Catholic. It varies over time, switching from one to zero, only for the three cities in the dataset that, after introducing the Reformation in the 16th century, switched their denomination between 1600 and 1624. For expositional simplicity, I will use the notation Prot $_{i}$ instead of Prot ${ }_{i t}$. All regressions are substantially unchanged if I drop these switching cities from the database.
} 
The treatment effects of Protestantism are, however, unlikely to be constant over the whole time period considered, from the beginning of the Reformation in 1517 until 1900. An alternative setup would model the treatment effects as a linear function of time:

$$
\begin{aligned}
\ln \left(u_{i t}\right)= & \chi_{i}+\chi_{t}+\sum_{\tau \in\{1300,1400\}} \alpha_{\tau} \cdot \operatorname{Prot}_{i} \cdot I_{\tau} \\
& +\alpha_{\text {post }} \cdot \operatorname{Prot}_{i} \cdot \operatorname{Post} 1517_{t}+\alpha_{\text {posttrend }} \cdot \operatorname{Prot}_{i} \cdot \operatorname{Post}_{1517_{t}} \cdot \text { Trend }_{t}+\varepsilon_{i t}
\end{aligned}
$$

The coefficient $\alpha_{\text {post }}$ represents an average post-treatment difference in city size; in addition to that, $\alpha_{\text {posttrend }}$ captures any linear evolution of city size differences over time. The time trend Trend $d_{t}$ is defined as $(t-1517) / 100$, and is hence measured in centuries. Furthermore, one can control for pre-trends in the set of cities that would later become Protestant. This is obtained through the inclusion of interaction terms of $\operatorname{Prot}_{i}$ with time dummies $I_{\tau}$ for the years 1300 and 1400; the corresponding coefficients are labeled $\alpha_{\tau}$.

The most flexible approach would allow the treatment effects of Protestantism to vary arbitrarily in any time period considered, by interacting the variable Prot ${ }_{i}$ with a full set of dummies for every time period in the dataset (except one):

$$
\ln \left(u_{i t}\right)=\chi_{i}+\chi_{t}+\sum_{\tau \in \Gamma} \alpha_{\tau} \cdot \operatorname{Prot}_{i} \cdot I_{\tau}+\varepsilon_{i t}
$$

The set $\Gamma$ of Protestantism/year interactions included in the regression comprises all years in the dataset after the beginning of the Reformation, as well as 1300 and 1400 in order to check for pretrends, leaving the year 1500 as the omitted category. The corresponding coefficients $\alpha_{t}$ can be seen as the difference in log city size between Protestant and Catholic cities, conditional on city and time fixed effects, relative to the difference in log city size in the omitted year, 1500.

The regression results can be seen in Table 5; panels A-C reflect the setups of equations 1-3, respectively. From the estimates in column (1), there appear to be no economic effects of Protestantism. Almost all of the coefficients are far from conventional levels of significance. In the simple differences-in-differences regression of panel A, the estimated effect suggests a minuscule and not 
significant difference in log city size (0.022). When analyzing how the effect of Protestantism varies over time in the fully flexible setup of panel $C$, three facts stand out. First, a negative effect appears in 1700: this can be attributed to the greater damage sustained by the Protestant areas during the Thirty Years' War (1618-1648). Second, the coefficients become markedly positive, while still small in magnitude and not significant, towards the end of the 19th century. Finally, there are no indications of a pre-trend, as evidenced by the small and insignificant coefficients relating to 1300 and 1400. A test of joint significance of all post-1517 coefficients (i.e., the interactions of "Protestant" with all year dummies from 1600 onwards) rejects the null (p-value: 0.017); however, this is due largely to the one negative coefficient in 1700 . When testing the joint significance of the coefficients relating to the years 1750 and later, the null is not rejected, with a p-value of 0.292.

\section{[Table 5 about here]}

As evident from the summary statistics in Table 2, cities that would later become Protestant are different from their Catholic counterparts along a wide array of characteristics. To the extent that these time-invariant characteristics (such as geographic features) have a constant effect on city size, this is captured by the city fixed effects. It is conceivable, though, that these features exert an effect on city size that varies over time; for example, distance to the Atlantic ports may be important only in the period after 1500, after the discovery of the Americas. Following a setup similar to equation (3), we can investigate this and other hypotheses by interacting time-invariant characteristics of cities, control $_{i}$, with a full set of time dummies:

$$
\ln \left(u_{i t}\right)=\chi_{i}+\chi_{t}+\sum_{\tau \in \Gamma} \alpha_{\tau} \cdot \operatorname{Prot}_{i} \cdot I_{\tau}+\sum_{\tau \in \Gamma} \beta_{\tau} \cdot \text { control }_{i} \cdot I_{\tau}+\varepsilon_{i t}
$$

Analogously, a full set of interactions of control variables with time dummies can be included in the regression setups of equations (1) and (2).

Column (2) reports the results of a regression including the full set of interactions of year dummies with latitude and longitude; while the estimates of these interactions (not reported) are mostly significant, the coefficients capturing the economic effects of Protestantism are mostly unchanged, being generally slightly lower than before. The negative performance of Protestant 
cities during the 17th century is now clearer and weakly significant, whereas the pickup in trends towards the end of the 19th century is now less evident.

More concretely, one can consider why latitude and longitude should affect economic outcomes, and what they are proxying for. The former can be seen as proxying for the closeness to the seaports of the North and Baltic seas. The latter proxies for the distance from the commercial centers of Western Europe as well as for the age of the city: the further east, the younger cities are, as they were founded during the eastward movement of the Germanic populations during the 10th-13th century. In that sense, any differential growth pattern of cities located further east could be seen as convergence toward a city-specific steady state of cities starting smaller. Column (3) controls for time-varying effects of distance to the Atlantic ports and city size in 1300; this is a very flexible way to control for long-run convergence patterns. The results from this setup largely confirm the prior estimates in column (2). In all further regressions, I control for time-varying effects of initial city size and distance to Atlantic ports, unless otherwise noted.

Columns (4)-(6) investigate an alternative hypothesis: in this case, the dependent variable is not total population of a single city, but rather total urban population by territory. Based on the Bairoch et al. (1988) dataset, I aggregate the population of cities at the level of territories; the latter are defined using historical borders, keeping the borders constant over the period analyzed. ${ }^{18}$ This specification controls for the extensive margin of urban growth: some territories might have become more urbanized by creating a series of new, smaller cities, rather than by continuously increasing the size of existing cities. ${ }^{19}$ Furthermore, there could be general equilibrium effects, whereby the agglomeration of economic activity into one city occurs to the detriment of other urban centers in the same territory.

The results of the estimates in columns (4)-(6) are very similar to the regressions which use city size as the dependent variable. Again, there is a negative effect stemming from the Thirty Years'

\footnotetext{
${ }^{18}$ In general, if territories changed hands or lost their independence, they would do so as a whole and would still be treated as distinct units. For example, the Duchy of Cleves was given to the Margraves of Brandenburg as a result of the Treaty of Xanten (1614); however, the Duchy of Cleves continued to exist as a legal unit afterwards, and the Margrave of Brandenburg would simply add "Duke of Cleves" to his collection of titles. Therefore, the Duchy of Cleves is considered a "territory" throughout the period considered in the dataset.

${ }^{19}$ Note, however, that only 11 cities among those in my dataset were founded after 1517. Entry into the dataset occurs mainly because many cities, while already existing, are too small and have no reported population sizes for the earlier dates.
} 
War in the Protestant territories, and a slight Protestant advantage in the later years of the dataset. However, this latter finding is weakened in columns (6) and (7) with the inclusion of time-varying effects of latitude, longitude, distance to the Atlantic or initial urban population.

\subsection{Interpreting the magnitude of estimated effects}

Given the inability to reject the null hypothesis of no effect of Protestantism, it is important to determine whether this inability is due to the small power of the statistical tests applied. In fact, though, the sample size is comparatively large (almost 1900 observations) and the standard errors relatively small, being in the same order of magnitude as the point estimates. To reinforce this observation, one can try to gauge the magnitude the precision of the effect by considering the $95 \%$ confidence interval around the point estimates, and see which magnitudes of the effect can be safely excluded.

Figure 3 gives a visual representation of the baseline estimates of Table 5, columns (1) and (3), panel C. In both cases, the upper confidence bounds lie around 0.2-0.4, which would suggest that, conditional on the covariates, Protestant cities are at most $22-49 \%$ larger than their Catholic counterparts. A log difference of 0.2-0.4 corresponds to approximately one third of the standard deviation of log city sizes in the dataset for any of the years 1750-1900. That is, even the upper bound of the confidence interval suggests that the implied effect of Protestantism are at best minor.

\section{[Figure 3 about here]}

An alternative way to gauge the magnitude of coefficients relating to city sizes is to model explicitly how shocks to urban productivity affect city sizes. In a simple model of a Malthusian economy, population size reacts to shocks in productivity (as they could have arguably occurred through the adoption of Protestantism). The elasticity of city size with respect to productivity shocks is determined by the elasticity of output with respect to the reproducible factor of production, labor. ${ }^{20}$ If $\beta<1$ is the elasticity of output with respect to labor, city sizes react to shocks in

\footnotetext{
${ }^{20}$ Assume, e.g., a production function of the type $Y=A L^{\beta} \Lambda^{1-\beta}$, where $\Lambda$ is a factor of production in limited supply. There are no property rights over $\Lambda$; real incomes are given by the average product of labor and are constant (population adjusts correspondingly to shocks in $A$ ). Alternatively, assume that $\Lambda$ belongs to a landlord who pays the marginal product of labor to workers, and is otherwise extraneous to the Malthusian dynamics of the model (see Galor 2005, p. 240).
} 
urban productivity with an elasticity equal to $1 /(1-\beta)$. This implies that, for the case of $\beta=0.5$, an upper bound to the increase in city size of $0.2-0.4 \log$ points can be caused by an increase to urban productivity of about $0.1-0.2 \log$ points, or $11-22 \%$.

Finally, one can compare these magnitude to other estimates of determinants of city size. Acemoglu et al. (2005b) use a very similar empirical setup to determine the effect of being located on an Atlantic port on log city size; the corresponding point estimates for the years 1700-1850 vary between 0.7 and 1.1 (table 5, p. 560). Thus it appears from this comparison that the upper bound for the effect of Protestantism is,, far from the effect that other likely determinants of growth can have on city size.

\subsection{Results in subsamples}

To investigate the robustness of these results, I apply the regression setup described in equation (4) to a series of subsets of my data. First, it is questionable to what extent city size can be used as an indicator of economic progress when free movement of labor from the countryside is hampered. In the territories east of the Elbe stronger forms of serfdom persisted until the early 19th century. Given that almost all cities east of the Elbe are Protestant, this may explain why their economic performance as reflected in city growth was not too strong. However, column (1) in Table 6, which reports results from a regression corresponding to the setup in equation (4), seems to disprove this conjecture. Even considering only cities west of the Elbe, the basic pattern is unaffected: Protestant cities grow slightly less than Catholic cities, but not significantly so, except for the substantial disruptions of the 17 th century.

\section{[Table 6 about here]}

This motivates another robustness check: controlling explicitly for the handicap caused by the Thirty Years' War (1618-1648) in Protestant parts of the Empire. For those cities that have reported population sizes for both 1600 and 1700 (this reduces the number of cities in the sample to 114), I interact the log-difference in population sizes from 1600 to 1700 with all time dummies relating to the years 1750 onward. This controls in a flexible fashion for the catchup process necessary in those 
cities that have experienced the largest levels of destruction during the Thirty Years' War. In addition, I include a set of triple interactions of "destruction during the 17th century," "Protestantism," and year dummies. These interactions test the hypothesis that Protestant cities were faster/slower in recovering from their destructions. In fact, while the estimates of the main coefficients on the Protestantism/year interactions are now generally larger (see column (2)), especially in the 19th century, they still fail to reach conventional levels of significance.

The panel dataset with city sizes is unbalanced, with only a small part of the cities having population sizes reported for all years. Even though unbalancedness is not generally a problem in panel data regressions with individual fixed effects, in column (3) I report results from a regression on the balanced dataset of cities for which population sizes are reported in all years. ${ }^{21}$ The results are now more clearly negative for Protestant cities, relative to the baseline regressions. In almost all years after the Reformation the coefficients are negative.

Additionally, column (4) checks whether the selection of cities into the dataset drives the results. Bairoch et al. (1988) include all cities that reach the threshold of 5000 inhabitants at any time before 1800. Therefore, presence in the dataset is already conditional on successful city growth. Instead, one could limit the regression to those cities that were already successful by 1500 , as measured by the fact that they have a population size reported for that year in Bairoch et al. (1988). This leaves 126 cities in the dataset, and hence excludes all localities that were very small or did not exist in 1500. Reassuringly, the results are not very different from the baseline estimates.

The 38 Free Imperial cities in the dataset enjoyed a radically different institutional setup than the territorial states of the Empire. In those cities, the decision whether to become Protestant was taken by a city council representing the urban elites, and not imposed by princely fiat. Furthermore, these cities (which were by a large majority Protestant) are often considered a relic of the medieval structure of the Empire, structurally unable to compete with the dominant polity of the early modern era, the territorial state. The results in column (5), which exclude Free Imperial cities from the sample, suggest that their growth performance in the years after the Reformation was

\footnotetext{
${ }^{21}$ Due to the Black Death which hit Europe in the 14th century, most cities have missing data for the year 1400; I therefore exclude the year 1400 from the balanced sub-dataset. Imposing the condition that the panel be balanced for all years, including 1400, would have further reduced the number of cities from 45 to 26 .
} 
indeed below average. The estimated coefficients are now larger and mainly positive, but again not significant.

To increase their size, cities relied mostly on migration from the surrounding countryside; the institutional structure of land tenure could therefore be a determining factor of city growth. In early modern Germany, regions with partible inheritance existed alongside areas with impartible inheritance. Based on Huppertz (1939, map I), I determine the prevailing inheritance rule in the region surrounding each city in the dataset; in general, the Rhineland, Baden, Württemberg, and parts of Hesse and Thuringia had partible inheritance rules, whereas the north, the east, and the southeast of the Empire had impartible inheritance rules. Columns (6) and (7) report results from regressions in the subsets of cities with impartible and partible inheritance rules separately. In fact, it appears that inheritance rules do not affect the main results substantially, as the estimates are similar in both cases, and comparable to the baseline case of Table 5 .

Finally, column (8) looks only at the subset of cities that were be part of Prussia in 1871, after the unification of Germany. This is the region considered in the analysis of Becker and Wößmann (2009); while the Electorate of Brandenburg-Prussia was originally Lutheran, it acquired several Catholic regions over the course of the centuries, in particular after the Congress of Vienna (1815). Here, again, there appears to be no strong effect of Protestantism on city size. ${ }^{22}$

\subsection{Lutheranism vs. Calvinism}

The vast majority of the territories considered in the analysis are Lutheran. If we take a more restrictive view of of Weber's original hypothesis, though, a positive effect on economic development should be expected in particular from the Reformed (i.e. Calvinist ${ }^{23}$ ) denomination, with its view on the doctrine of predestination. If this was true, the previous regressions in this paper,

\footnotetext{
${ }^{22}$ Becker and Wößmann (2009) find a positive correlation between Protestantism and economic outcomes in their sample, which — they argue — can be explained fully by differences in literacy. However, their main outcome variable, income tax returns, is not available for the 26 largest cities in Prussia. In general, the relationships found are much weaker or not present for the subsample of urban counties (see Becker and Wößmann 2009, fn. 25, 41, 42, 44). The discrepancy between urban and rural areas in Prussia toward the end of the 19th century likely explains the different findings in the present paper (cf. also the discussion in the introduction).

${ }^{23}$ Perhaps confusingly, not all religious denominations that emerged from the Protestant Reformation are "Reformed;" the latter term is used to classify Calvinist or Zwinglian (as opposed to Lutheran) branches.
} 
which pooled Lutheran and Reformed cities under the label "Protestant," might be misleading, and the estimated coefficient biased downwards.

Only a minority of German states chose to adopt the Reformed faith over the Lutheran alternative: the Rhenish Palatinate, Hesse, and Bremen are some of the few notable examples. These territories comprise 21 cities in my dataset, as opposed to 163 Lutheran cities. To test whether these cities have experienced a more favorable growth trajectory, I estimate a model equivalent to equation (4); instead of a binary variable reporting whether a city is Protestant, I use an indicator for the Reformed denomination, interacted with all relevant time dummies. Results in Table 7, column (1), are in fact very similar to the baseline results when considering all Protestant denominations together (as in Table 5): there is no evidence for pre-trends, but no evidence for any effect, positive or negative, after the inception of the Reformation, either.

\section{[Table 7 about here]}

While in column (1) the implicit comparison group are Lutheran and Catholic cities together, the specifications in column (2) introduce an analogous set of interactions between a "Lutheran" indicator and time dummies (coefficients not reported); in this case, the results can be interpreted as the difference between Reformed and Catholic cities only. The results, however, do not differ much, as all coefficients fail to reach conventional levels of significance. Finally, columns (3) and (4) use urban population aggregated at the level of territories as the dependent variable; again, no distinctive pattern of growth is discernible among the Reformed cities.

\subsection{Fertility and religious denomination}

For the validity of my empirical strategy, it is important to exclude the possibility that other factors interfere with the underlying Malthusian logic that allows to infer from city size to productivity. One potentially confounding factor is the behavior of fertility. If, at any given level of real income, Catholics have higher fertility rates than Protestants, inferring local productivity levels from total population size could be misleading. In a Malthusian environment, the increase in population that results from higher productivity levels (stemming, e.g., from a specific "Protestant ethic") 
can be offset by a lower fertility rate. This is true both for urban fertility rates-if we assume that city growth is mostly attributable urban reproduction rates-and for the fertility rates of the surrounding countryside, if we assume more realistically that most of the observed city growth is due to migration from the neighboring agricultural areas.

While it is known that Protestant areas in Germany went through the fertility transition of the late 19th century earlier than their Catholic counterparts (Galloway et al., 1994; Brown and Guinnane, 2002), there is little evidence on fertility levels across denominations in pre-industrial Germany. In his study of nine villages of the Empire, John Knodel (1978) found no systematic differences in fertility levels and their trends over time across Catholic and Protestant regions. Evidence for an urban setting in the 17th and 18th centuries is provided by Peter Zschunke (1984), who analyzes the fertility behavior of the population of Oppenheim, a rare tri-denominational city (Catholics, Lutherans and Calvinists). He finds that, in fact, Catholic women are more fertile than Protestant ones. At the same time, though, Catholics had a higher infant mortality, which cannot be simply explained by differences in income; the latter should have approximately compensated for the difference in fertility. ${ }^{24}$ Differences in fertility are hence unlikely to be a major confounding factor when comparing the growth performance of Catholic and Protestant cities.

Overall, these results show that Protestant (Lutheran and Calvinist) and Catholic cities followed very similar growth trajectories in the period 1300-1900. These findings are robust, hold in a series of subsets of the data, and are unlikely to be due to selection into the dataset, or small sample size.

\section{Endogenous adoption of the Reformation}

To understand the causal nexus between Protestantism and economic growth, we also need to shed light on the circumstances of adoption of the Reformation. For the large majority of the population

\footnotetext{
${ }^{24}$ Higher fertility among Catholic women was due to both shorter birth intervals and later stopping; the theoretical number of children per woman (neglecting mortality) was 11 for Catholics, 9 for Protestants. Survival at age 10 was 5-6 out of 10 newborn babies for Protestants, 4 out of 10 for Catholics (Zschunke, 1984, pp. 165, 200). Similar conclusions are drawn in Heller-Karneth (2000).
} 
in the Holy Roman Empire the new religion was imposed from above, enacting the principle of cuius regio, eius religio; this is even more true for the generations born after the Peace of Westphalia, whose religion had been determined by some princes' choices decades or centuries ago. However, in the 16th century rulers could have chosen to follow the new religion out of unobserved reasons that correlate with the potential for economic growth.

Two possible sorts of endogeneity are conceivable here. On the one hand, it could be that cities or territories which were already more inclined to commercial activity saw the growth-promoting potential of the Protestant Reformation and therefore chose to adopt it. In that case, cities with a predisposition for economic growth would be those that became Protestant, and OLS estimates would overstate the causal effect of Protestantism. Alternatively, it could be that cities with a higher potential for economic growth around 1500 chose to remain Catholic. The Catholic Church was famed for its rent-extraction practices (see Ekelund, Hébert and Tollison 2002), but it also guaranteed a legal and cultural framework to be shared with other trading partners; therefore, it could be that cities with more interest in economic activity chose the less risky alternative and remained Catholic. ${ }^{25}$

An instrumental variables strategy may alleviate these concerns about endogeneity. As first suggested by Becker and Wößmann (2009), the distance to Wittenberg—the city where Martin Luther first presented his 95 theses, and where he taught at the local university—can be used as an instrument that predicts the adoption of the Reformation across German territories. Being close to Wittenberg mattered less for the spread of ideas-in fact, thanks to the recent invention of the printing press, Luther's theses were rapidly known all over Germany within months ${ }^{26}$-but rather because of geopolitical considerations. Introducing the Reformation was a risky venture

\footnotetext{
${ }^{25}$ Weber shared the view that the Catholic Church practiced a form of control over social and economic affairs that was severe in principle, but flexible in practice: "[...] the Reformation meant not the elimination of the Church's control over everyday life, but rather the substitution of a new form of control for the previous one. It meant the repudiation of a control which was very lax, at that time scarcely perceptible in practice, and hardly more than formal, in favour of a regulation of the whole of conduct which, penetrating to all departments of private and public life, was infinitely burdensome and earnestly enforced. The rule of the Catholic Church, 'punishing the heretic, but indulgent to the sinner,' as it was in the past even more than today, is now tolerated by peoples of thoroughly modern economic character, and was borne by the richest and economically most advanced peoples on earth at about the turn of the fifteenth century." (Weber 1930, p. 36)

${ }^{26}$ As soon as 1519 Johannes Froben, a publisher from Basle, could write to Luther: "We have sent 600 copies to Spain and France, and now they are also sold in Paris. [...] Calvus, the bookseller in Pavia, a very erudite and scientific man, wants to bring some of these booklets to Italy and disseminate them in all cities. [...] I have sold almost all of my copies, only ten are remaining, and I have never had such a fortunate turnover with any other book." (Schilling, 1988)
} 
for a territorial lord, especially in the years until 1555, for the imperial troops under Charles V could have intervened and imposed the return to the old faith. Given this threat, a territory was more likely to embrace the Reformation if its neighbors had already done so; in this case, territorial closeness to a powerful Lutheran state, such as Saxony, could have provided easier military defense in case of military conflict. Saxony, the territory around Wittenberg, was an early adopter of Luther's ideas, the first one to reform the Mass, the first one to establish a territorial church, the first one to perform a church visitation already in the 1520s and 30s (Dixon, 2002, p. 122).

A graphic representation of the predictive power of distance to Wittenberg is given in Figure 4: no city closer than $200 \mathrm{~km}$ to Wittenberg remained Catholic. ${ }^{27}$ The simple correlation coefficient is equal to -0.482 , indicating a clear negative relationship between distance to Wittenberg and likelihood of adoption of Protestantism.

[Figure 4 about here]

Table 8 shows results from a regression predicting the adoption of the Reformation by 1600 at the level of cities or territories of the Holy Roman Empire; this can be seen as conceptually similar to a first-stage in a regression where "Protestantism" is the endogenous variable. ${ }^{28}$ The setup is a linear probability model, with a binary dependent variable. As evident from all columns, distance to Wittenberg is a strong and robust predictor; a city that is $100 \mathrm{~km}$ closer to Wittenberg is $15-20 \%$ more likely to become Protestant by 1600 . The t-statistic on the respective coefficients is always close to or larger than 5, eliminating any concern about weak instruments. Geneva and Zurich, the cities where Calvin and Zwingli lived and taught respectively, do not seem to have exerted a similar spatial influence on the religious decisions of German states (column (3)). The only other robust and strong predictor of Protestantism is whether a territory was ecclesiastical, i.e. ruled by a prince-bishop; not surprisingly, this makes a territory less likely to embrace the Reformation. Any other potential confounding factors are, as shown in columns (4) or (6), unable to affect the coeffi-

\footnotetext{
${ }^{27}$ Distance to Wittenberg is computed as great circle distance ("as the crow flies"). Given the absence of major natural obstacles (e.g. large mountainous chains) in Germany's physical geography, this can be taken as a reasonable approximation of actual travel time.

${ }^{28}$ In the setup used to analyze the full panel dataset, the actual first stage will be different due to the presence of city and time fixed effects, and the interaction of "Protestantism" with year dummies. However, the strength and robustness of distance to Wittenberg as predictor of adoption of Protestantism hold as well in the IV setup.
} 
cient relating to the distance to Wittenberg. Not even wealth or strength of a territory, as measured by its contribution to the expenditures of the Empire as a whole (Reichsmatrikel ${ }^{29}$ ), predict whether a territory adopted the Reformation, rejecting the widely-held assumption (also shared by Weber) that richer territories were more likely to become Protestant (column (6)).

\section{[Table 8 about here]}

Is it reasonable to use distance to Wittenberg as an instrumental variable; i.e., are there any other reasons for which distance to Wittenberg might matter for economic growth, except through the promotion of the adoption of Protestantism? At the time of the Reformation, Saxony seemed if anything less likely than other states to accept someone like Martin Luther; the Prince Elector, Frederick the Wise, was a fervently devout Christian and an avid collector of reliquaries. Precisely around that time, Frederick the Wise was a likely candidate to be elected as Emperor of the Holy Roman Empire, an election for which he needed and seemed to have the Pope's support. It was under these circumstances that Martin Luther's protest was heard in Wittenberg, and Frederick exploited the issue to obtain more concessions from both sides. However, in the following decades and centuries Saxony would not regain this pivotal role any more. The loss of the electoral privilege and the division into many different lines of succession would make the territory of Martin Luther and Frederick the Wise a marginal player in the Empire's economic and political destinies. It is unlikely that this rather fortuitous set of circumstances happening around 1517 should be correlated with the error term, let alone for the territories surrounding the Electorate of Saxony.

Does distance from Wittenberg correlate with other geographically distributed factors that do, in fact, have an influence on economic potential? It is hard to spot one preeminent geographical factor in early modern Germany that would determine the economic potential of cities, and which would at the same time display some correlation with distance to Wittenberg. Consider the following candidates for omitted variable: being at the foot of the Alps, next to the connecting paths to the commercial centers of Northern Italy; or being on the Rhine, ready to sail down towards the Atlantic ports, and being able to extract rents from passing ships; distance to the iron ore and

\footnotetext{
${ }^{29}$ The Reichsmatrikel was a key for allocating Imperial expenses among the different territories from 1521 until the end of the Empire.
} 
gold mines of the Bohemian forest; or being a port on the North Sea or the Baltic Sea. These are all conceivable sources of economic advantage that have a clear geographic pattern. None of them, though, shows any sign of correlation with distance to Wittenberg. The only potentially worrisome correlation is with longitude, as Wittenberg lies in the eastern half of the Empire, and this might correlate with the age (and hence initial size) of cities. As already remarked in the context of Table 5, however, I control for time-varying effects of initial city size. ${ }^{30}$

A regression setup taking into account the endogeneity of the decision to adopt the Reformation would be equivalent to equations (1)-(3), but where the interaction terms including Prot $_{i}$ are instrumented by the respective interaction terms with the instrumental variable instead. Conceptually, for the case of equation (3) this can be seen as equivalent to the following two-stage least squares setup:

$$
\begin{aligned}
\ln \left(u_{i t}\right) & =\chi_{i}+\chi_{t}+\sum_{\tau \in \Gamma} \alpha_{\tau} \cdot \widehat{\text { Prot }_{i} \cdot I_{\tau}}+\varepsilon_{i t} \\
\operatorname{Prot}_{i} \cdot I_{t} & =\xi i+\xi_{t}+\sum_{\tau \in \Gamma} \gamma_{\tau} \cdot(\text { DistanceWittenberg })_{i} \cdot I_{\tau}+\eta_{i t} \quad \forall t \in \Gamma
\end{aligned}
$$

where $\xi_{i}$ and $\xi_{t}$ are city and time fixed effects respectively. An analogous setup can be conceived for the cases of equations (1), (2), and (4). In fact, now all regressions replace the indicator for "Protestant" by the component that can be explained by the distance to Wittenberg in all interaction terms.

\section{[Table 9 about here]}

Regression results using distance to Wittenberg as an instrument can be seen in Table 9; like Table 5, it is divided in three panels, corresponding to the IV analogues of regression equations (1)(3). The first column reports the baseline results, whereas the other columns introduce control variables interacted with time dummies. As opposed to the OLS results, now all coefficients of interest in column 1 are positive; however, none of them reaches conventional levels of significance, not even jointly ( $\mathrm{p}$-value=0.396). This weakly positive result is further questioned by the results in

\footnotetext{
${ }^{30}$ Becker and Wößmann (2009) discuss the exogeneity of the Wittenberg instrument analyzing the correlation with a variety of plausible economic outcomes of the early 16th century (table 4, p. 561).
} 
columns (2)-(3), which show how the estimates are affected by allowing for time-varying effects of city characteristics. While controlling for initial city size and distance to Atlantic ports delivers results very similar to the baseline case of column (1), the inclusion of latitude and longitude interacted with year dummies yields results that are mostly negative, without a clear pattern though. Figure 5 gives a visual representation of the IV estimates, both with and without controls; as can be generally expected, the coefficients are estimated less precisely than their OLS counterparts.

[Figure 5 about here]

The last three columns present results at the level of territories, analogously to Table 5. Again, the results in column (4) are generally larger than their OLS counterparts, but fail to reach conventional levels of significance. Moreover, we can reject a test of joint significance of all interactions after 1500 (p-value 0.196). These results are corroborated by the findings of columns (6) and (7), which are again mostly positive but not significant.

In sum, the findings from instrumental variables regressions in Table 9 shed light on the causality nexus between Protestantism and economic growth. The estimated coefficients for the periods 1600 and onwards are generally larger than their OLS counterparts, suggesting a negative selection in the camp of Protestantism: cities with an intrinsically lower potential for economic growth chose to adopt the Reformation. However, there seems to be no significantly positive, causal impact of Protestantism on the growth of German cities, even when this negative selection is taken into account.

\section{Alternative hypotheses: Protestantism and city characteristics}

This section explores a series of alternative hypotheses, investigating whether Protestantism has an effect when combined with certain city characteristics. While the previous sections have shown that there is no broad impact of Protestantism on city growth over the entire set of cities in the dataset, it could be the case that some cities, sharing a certain set of characteristics, have benefited from the Protestant faith, whereas cities lacking those characteristics were not able to reap any 
benefits. As discussed in section 2.1, different theories about the links between Protestantism and economic growth can lead to different hypotheses as to where and when to look for the purported effects. To the extent that these hypotheses can be mapped to measurable characteristics of cities, one can investigate how the impact of Protestantism on city size varies according to these control variables.

A general setup suitable for this purpose can be constructed in analogy to to equation (3):

$$
\ln \left(u_{i t}\right)=\chi_{i}+\chi_{t}+\sum_{\tau \in \Gamma} \alpha_{\tau} \cdot \operatorname{Prot}_{i} \cdot I_{\tau}+\sum_{\tau \in \Gamma} \beta_{\tau} \cdot \operatorname{control}_{i} \cdot I_{\tau}+\sum_{\tau \in \Gamma} \gamma_{\tau} \cdot \operatorname{control}_{i} \cdot \operatorname{Prot}_{i} \cdot I_{\tau}+\varepsilon_{i t}
$$

While the coefficients $\beta_{t}$ capture the baseline, time-varying effect of a certain city characteristic control $_{i}$ (analogously to equation (4)), the coefficients $\gamma_{i}$ relating to the triple interaction report whether Protestantism affects city size when combined with certain city characteristics, and how this effect varies over time. The estimates from regression (7) are unwieldy to present, resulting in 27 estimated coefficients, besides the city and time fixed effects. For this reason, the full tabular representation of these results is limited to Appendix C. Instead, I will discuss the hypotheses in the context of this section by comparing graphically the performance of cities that lie at the upper and lower ends of the empirically observed distribution of the control variable. The graphic depiction of results in this section, therefore, represents the "treatment effects" of Protestantism on a city that is at the 90th or, respectively, 10th percentile of the distribution of the control variable (relative to a hypothetical Catholic city that at the same percentile).

\section{[Figure 6 about here]}

Hypothesis 1: Protestantism benefited cities close to the Atlantic seaports. The discovery of the Americas and the beginning of worldwide trade had a momentous impact on the economic geography of Europe, giving a distinct advantage to those regions facing the Atlantic coast (see, e.g, Acemoglu et al., 2005b). In the context of this paper, it is conceivable that Protestants, because of their different business ethics, were more rapid to capture the gains from these new opportunities. 
In fact, the results of the first graph of Figure 6 lend only weak support to this hypothesis. The solid line with a grey shadow refers to the difference between a Protestant and a Catholic city that are both located at the 10th percentile of the distribution of distance to the Atlantic $(128 \mathrm{~km})$, the dashed line and confidence interval refers to the difference between a Protestant and a Catholic city that are located at the 90 th percentile $(571 \mathrm{~km})$. The combined interaction terms suggest that Protestant cities were relatively larger than their Catholic counterparts when close to the Atlantic ports. However, this finding is mostly due to the differential impact of the Thirty Years' War, as the difference between the two performances is particularly evident in $1700 .{ }^{31}$ Toward the end of the period analyzed, these differences wane.

Hypothesis 2: Protestantism benefited trading cities. Another crucial variable is the productive structure of cities. If Protestantism is associated with a kind of ethics particularly favorable to commercial enterprise, e.g. by allowing the charging of interest and more sophisticated financial instruments, rather than with a work ethic useful in all kinds of production, we should see a differential effect in those cities with a specific potential for commerce. A proxy for the potential for commerce is the geographic location on a (navigable) river or a seaport. The results represented in the second graph of Figure 6, though, disprove this conjecture. Cities on rivers or seaports and those without have very similar trajectories.

Hypothesis 3: Protestantism benefited cities close to coal deposits. Coal was the most important fossil fuel until the 20th century; a large part of the technological innovations of the industrial revolution were related to the exploitation of its caloric content into mechanical movement. It is therefore natural to think that distance to coal deposits mattered for industrialization. Moreover, it could be that Protestants, due to their openness to technological innovation (Merton, 1938), have gained relatively more from the presence of coal. The visual representation in Figure 6 (center left) compares the estimated effects for Protestant vs. Catholic cities located at the 10th percentile of

\footnotetext{
${ }^{31}$ In fact, the ravages of the Thirty Years' War were particularly strong in the southwest and in the center of the Empire (Franz, 1979).
} 
the distribution of distance to coal deposits $(23 \mathrm{~km})$ and cities at the 90 th percentile $(287 \mathrm{~km})$; while these results should be treated with caution, due to the large standard errors, it seems also clear that no distinct pattern of differentiation emerges.

Hypothesis 4: Protestant cities benefited from the seizure of Church holdings. A commonly held view is that Protestant states enriched themselves through the expropriation of Church holdings; if the confiscated capital is put to better use when in state or private hands, rather than if left to the Church, this would give a growth advantage to those cities that had more Church possessions at the time of the Reformation. A good proxy for the amount of capital that can be seized from the Church is the density of monasteries in a city around 1517 (measured as number of monasteries per 1000 inhabitants); monasteries held both prime pieces of real estate, as well as substantial swathes of agricultural land outside of the city walls. Again, however, the results in Figure 6 (center right) appear to disprove this hypothesis. There, I compare the performance of Protestant cities (relative to Catholic ones) with no monasteries around 1517 (10th percentile) and cities with four monasteries per 1000 inhabitants (90th percentile), evidencing again the absence of relevant patterns.

Hypothesis 5: Catholic cities profited from the presence of Protestant cities nearby. If Protestant cities were indeed endowed with a peculiar worth ethic or other advantages that translated into higher productivity, it is conceivable that other, neighboring cities would have profited from it though trade or local dissemination of knowledge, even while remaining Catholic. In this case, conventional estimates trying to detect a treatment effect of Protestantism would be biased downward because of these local spillovers. To investigate this hypothesis, I constructed a measure of "religious competition" representing, for each city, the percentage of cities lying within a range of $100 \mathrm{~km}$ that share the same religious denomination.

The last graph in Figure 6 displays the treatment effects for two different types of cities: cities that lie in an area with low religious competition (10th percentile, equivalent to $0 \%$ of nearby cities having a different religion) and cities in mixed areas, defined as having half of the neighboring 
cities with a different religion. If spillover effects were present, we would expect the growth performances of Catholic and Protestant cities in mixed areas to be very similar (leading to estimated treatment effects close to zero), and the performance of cities in religiously homogenous areas to be different. However, the results in the graph show how similar the estimated treatment effects for Protestant cities in either surrounding are.

\section{Interpretation and Conclusion}

Max Weber, in his seminal work, proposed what might be the most famous theory about the impact of cultural factors, namely beliefs about religion and afterlife, on economic growth. Despite its renown, this theory has rarely been tested empirically in a systematic fashion. The evidence presented in this paper points consistently towards the absence of any differences in the long-run performance of Protestant and Catholic regions. In light of the various theories that suggest that Protestants should be more inclined to economic activity, this result is surprising. Three broad categories of facts can explain the absence of results.

The first relates to ideological aspects. Many theories of Protestant advantage, most notably Max Weber's, are in fact based on an analysis of the doctrines of Calvinists or of minor Protestant sects, such as the Puritans, and not on the teachings of Lutheranism, the largest denomination in Germany. While I have found no substantial differences between Calvinist and either Catholic or Lutheran territories of the Holy Roman Empire, I cannot exclude that other, minor religious groups had an ideology that was conducive to economic growth. Testing this latter hypothesis, however, would be difficult, as it is much more difficult to find exogenous sources of variation of sect membership, and because it is hard to disentangle the impact of religious beliefs from the status of belonging to a minority. ${ }^{32}$

The second set of reasons can be classified as "institutional." If we consider the institutional structure as the main determinant of the economic performance of a territory (Acemoglu et al., 2005a), there are reasons to think that the latter was generally not so different in Catholic and

\footnotetext{
${ }^{32}$ On a similar topic, see Botticini and Eckstein (2005).
} 
Protestant states. Measured by modern standards of democracy and security of property rights, all German states did not fare well until the 19th century.

The more interesting historical process in the period considered, however, is the creation of the modern territorial state, through the abolition of local privileges and the creation of a centralized bureaucratic state apparatus. ${ }^{33}$ In this respect, both Protestant and Catholic states in Germany seem to have profited from the Reformation, resulting in a zero net effect of Protestantism. Protestants clearly were advantaged by the ability to unite the secular and spiritual powers in one hand, as emphasized in the analysis of Ernst Troeltsch (see p. 6 in this paper). But through the parallel development of the Counter-Reformation, the Catholic church gave its temporal rulers similar powers to enforce both religious doctrine and social discipline. ${ }^{34}$

Finally, a reason why Protestant areas do not seem to fare any better than their Catholic counterparts in the present dataset might be related with the urban setting analyzed. Cities, with their varied population of artisans, traders, scholars and merchants, might have been just as cosmopolitan and open to new business practices in either a Catholic or a Protestant setting. In addition, if literacy is the key ingredient for economic growth, as suggested by Becker and Wößmann's (2009) interpretation, the little evidence available for the pre-industrial period before 1800 suggests that in an urban setting literacy rates were relatively high by international standards even in Catholic cities (François, 1977). ${ }^{35}$

While there are many reasons to expect Protestant cities and states to have been more economically dynamic during the past centuries-because of their work ethic, their attitude toward business, their encouragement of literacy—-the present paper finds that there is no effect of religious denominations on a likely indicator of economic development, city size. Despite their differing

\footnotetext{
${ }^{33}$ These are some of the aspects described by Tilly (1990) as the move, dated around the year 1700, from the paradigm of "brokerage" to the model of "nationalization."

${ }^{34}$ These parallel processes are known in historiography as Confessionalization. The seminal article on this topic is Reinhard (1977); for an overview, see Boettcher (2004).

${ }^{35}$ In fact, this result could be another success of the Counter-Reformation movement, which through the institution of the Jesuits and other orders placed importance on the education of the youth and the pursuit of knowledge. The British historian John Bossy summed this up: "[...] the bishops of the Tridentine Church have more positive achievements to their credit than they are often allowed: from the parish register to the primary school they were laying many of the foundations of the modern state, and perhaps they have as good a claim as English Puritanism to have 'eradicate[d] habits which unfitted men for an industrial society'" (Bossy, 1970, p. 70).
} 
views on religious matters, Protestants and Catholics might not have been so different in their economic behavior after all. 


\section{References}

Acemoglu, Daron, Simon Johnson, and James A. Robinson, "Institutions as a Fundamental Cause of Long-Run Growth," in Philippe Aghion and Steven N. Durlauf, eds., Handbook of Economic Growth, Vol. 1, Amsterdam: Elsevier, 2005, chapter 6, pp. 385-472.

${ }_{-},{ }_{-}$, , and $\ldots$, , "The Rise of Europe: Atlantic Trade, Institutional Change, and Economic Growth," American Economic Review, June 2005, 95 (3), 547-579.

Bairoch, Paul, Taille des villes, conditions de vie et développement économique, Paris: Éditions de l'École des Hautes Études en Sciences Sociales, 1977.

_ , Cities and Economic Development, Chicago: University of Chicago Press, 1988.

_ , Jean Batou, and Pierre Chèvre, La population des villes européennes, 800-1850: Banque de données et analyse sommaire des résultats, Geneva: Droz, 1988.

Barro, Robert J. and Rachel M. McCleary, "Religion and Economic Growth across Countries," American Sociological Review, October 2003, pp. 760-781.

Becker, Sascha O. and Ludger Wößmann, "Was Weber Wrong? A Human Capital Theory of Protestant Economic History," Quarterly Journal of Economics, May 2009, 124 (2), 531-596.

_ , Erik Hornung, and Ludger Wößmann, "Education and Catch-up in the Industrial Revolution," American Economic Journal: Macroeconomics, 2011, (forthcoming).

Blum, Ulrich and Leonard Dudley, "Religion and Economic Growth: Was Weber Right?," Journal of Evolutionary Economics, 2001, 11, 207-230.

Boettcher, Susan R., "Confessionalization: Reformation, Religion, Absolutism, and Modernity," History Compass, January 2004, 2 (1), 1-10.

Bossy, John, "The Counter-Reformation and the People of Catholic Europe," Past and Present, May $1970,47,51-70$.

Botticini, Maristella and Zvi Eckstein, "Jewish Occupational Selection: Education, Restrictions, or Minorities?," Journal of Economic History, December 2005, 65 (4), 922-48.

Braudel, Fernand, The Wheels of Commerce, Vol. 2 of Civilization and Capitalism, New York: Harper \& Row, 1982.

Brentano, Lujo, Die Anfänge des modernen Kapitalismus, München: Verlag der K. B. Akademie der Wissenschaften, 1916.

Brown, John C. and Timothy W. Guinnane, "Fertility transition in a rural, Catholic population: Bavaria, 1880-1910," Population Studies, 2002, 56, 35-50.

de Vries, Jan, European Urbanization, 1500-1800, Cambridge, Mass.: Harvard University Press, 1984.

Delacroix, Jacques and François Nielsen, "The Beloved Myth: Protestantism and the Rise of Industrial Capitalism in Nineteenth-Century Europe," Social Forces, December 2001, 80 (2), 509553. 
Dickens, A. Geoffrey, "Intellectual and Social Forces in the German Reformation," in Wolfgang J. Mommsen, ed., Stadtbürgertum und Adel in der Reformation, Stuttgart: Klett-Cotta, 1979.

Dixon, C. Scott, The Reformation in Germany, Oxford: Oxford University Press, 2002.

Ekelund, Robert B., Robert F. Hébert, and Robert D. Tollison, "An Economic Analysis of the Protestant Reformation," Journal of Political Economy, 2002, 110 (3), 646-671.

François, Etienne, "Die Volksbildung am Mittelrhein im ausgehenden 18. Jahrhundert," Jahrbuch für Westdeutsche Landesgeschichte, 1977, 3, 277-304.

Franz, Günther, Der Dreißigjährige Krieg und das deutsche Volk, 4th ed., Stuttgart: G. Fischer, 1979.

Galloway, Patrick R., Eugene A. Hammel, and Ronald D. Lee, "Fertility Decline in Prussia, 18751910: A Pooled Cross-Section Time Series Analysis," Population Studies, 1994, 48 (1), 135-158.

Galor, Oded, "From Stagnation to Growth: Unified Growth Theory," in Philippe Aghion and Steven N. Durlauf, eds., Handbook of Economic Growth, Vol. 1, Amsterdam: Elsevier, 2005, chapter 4, pp. 171-293.

Grier, Robin, "The Effect of Religion on Economic Development: A Cross National Study of 63 Former Colonies," Kyklos, February 1997, 50 (1), 47-62.

Guiso, Luigi, Paola Sapienza, and Luigi Zingales, "People's opium? Religion and economic attitudes," Journal of Monetary Economics, 2003, 50, 225-282.

_ , , , and _ , "Does Culture Affect Economic Outcomes?," Journal of Economic Perspectives, Spring 2006, 20 (2), 23-48.

Hammel-Kiesow, Rolf, Die Hanse, München: C.H. Beck, 2000.

Hauser, Henri, Les débuts du capitalisme, Paris: F. Alcan, 1927.

Heller-Karneth, Eva, "Konfession und Demographie - Plädoyer für eine differenzierte Betrachtung," in Michael Matheus and Walther G. Rödel, eds., Landesgeschichte und historische Demographie, Stuttgart: Franz Steiner, 2000, pp. 69-80.

Hill, Christopher, "Protestantism and the Rise of Capitalism," in F.J. Fisher, ed., Essays in the Economic and Social History of Tudor and Stuart England, Cambridge: Cambridge University Press, 1961, pp. 15-39.

Huppertz, Barthel, Räume und Schichten bäuerlicher Kulturformen in Deutschland, Bonn: L. Röhrscheid, 1939.

Iyigun, Murat, "Luther and Suleyman," Quarterly Journal of Economics, November 2008, 123 (4), 1465-1494.

Jürgensmeier, Friedhelm and Regina E. Schwerdtfeger, eds, Orden und Klöster im Zeitalter von Reformation und katholischer Reform, 1500-1700, Münster: Aschendorff, 3 vols., 2005-2008.

Keyser, Erich, Deutsches Städtebuch, Stuttgart: Kohlhammer, 5 vols., 1939-1974. 
Knodel, John, "Natural Fertility in Pre-industrial Germany," Population Studies, November 1978, 32 (3), 481-510.

Krug, Leopold and Alexander August Mützell, Neues Topographisch-statistisch-geographisches Wörterbuch des preussischen Staates, Halle: Karl August Kümmel, 1825.

Kunz, Andreas, ed., Statistik der Binnenschiffahrt in Deutschland 1835-1989, Vol. 1, St. Katharinen: Scripta Mercaturae, 1999.

La Porta, Rafael, Florencio Lopez de Silanes, Andrei Shleifer, and Robert W. Vishny, "Trust in Large Organizations," American Economic Review, May 1997, 87 (2), 333-338.

Merton, Robert K., Science, Technology and Society in Seventeenth Century England, Vol. 4 of Osiris, Bruges: Saint Catherine Press, 1938.

Mitch, David, "The Role of Education and Skill in the British Industrial Revolution," in Joel Mokyr, ed., The British Industrial Revolution: An Economic Perspective, Boulder, Colo.: Westview, 1999, pp. 241-279.

Moeller, Bernd, Reichsstadt und Reformation, Berlin (GDR): Evangelische Verlagsanstalt, 1987.

North, Douglass C. and Robert P. Thomas, The Rise of the Western World: A New Economic History, Cambridge: Cambridge University Press, 1973.

Offenbacher, Martin, Konfession und soziale Schichtung: Eine Studie über die wirtschaftliche Lage der Katholiken und Protestanten in Baden, Tübingen: J.G.B. Mohr (Paul Siebeck), 1900.

Ozment, Steven E., The Reformation in the Cities: The Appeal of Protestantism in Sixteenth Century Germany and Switzerland, New Haven: Yale University Press, 1975.

Putnam, Robert, Making democracy work: Civic traditions in modern Italy, Princeton, N.J.: Princeton University Press, 1993.

Reekers, Stephanie, "Beiträge zur statistischen Darstellung der gewerblichen Wirtschaft Westfalens um 1800. Teil 1: Paderborn und Münster," Westfälische Forschungen, 1964, 17, 83-171.

Reinhard, Wolfgang, "Gegenreformation als Modernisierung? Prolegomena zu einer Theorie des konfessionellen Zeitalters," Archiv für Reformationsgeschichte, 1977, 68, 226-52.

Robertson, Hector M., Aspects of the Rise of Economic Individualism, Cambridge: Cambridge University Press, 1933.

Samuelsson, Kurt, Religion and Economic Action, New York: Basic Books, 1961.

Sandberg, Lars G., "The Case of the Impoverished Sophisticate: Human Capital and Swedish Economic Growth before World War I," Journal of Economic History, March 1979, 39 (1), 225-241.

Schilling, Heinz, Aufbruch und Krise: Deutschland 1517-1648 Das Reich und die Deutschen - Siedler Deutsche Geschichte, Berlin: Siedler, 1988.

Schindling, Anton and Walter Ziegler, eds, Territorien des Reichs im Zeitalter der Reformation und Konfessionalisierung, Münster: Aschendorff, 7 vols., 1993. 
Schmidt, Georg, Der Städtetag in der Reichsverfassung: Eine Untersuchung zur korporativen Politik der Freien und Reichsstädte in der ersten Hälfte des 16. Jahrhunderts, Stuttgart: Steiner, 1984.

Scribner, Robert, "Germany," in Robert Scribner, Roy Porter, and Mikuláš Teich, eds., The Reformation in national context, Cambridge: Cambridge University Press, 1994, chapter 1, pp. 4-29.

Tabellini, Guido, "Culture and Institutions: Economic Development in the Regions of Europe," 2009. Forthcoming, Journal of the European Economic Association.

Tawney, Richard H., Religion and the Rise of Capitalism, London: J. Murray, 1926.

Tilly, Charles, Coercion, Capital, and European States, AD 990-1990, Oxford: Blackwell, 1990.

Troeltsch, Ernst, The Social Teaching of the Christian Churches, Vol. 2, London, New York: Allen \& Unwin, 1931.

Weber, Max, "Die protestantische Ethik und der 'Geist' des Kapitalismus," Archiv für Sozialwissenschaften und Sozialpolitik, 1904/05, 20-21, 17-84; 1-110. English Translation: The Protestant Ethic and the Spirit of Capitalism, London: Allen \& Unwin, 1930.

Zeumer, Karl, ed., Quellensammlung zur Geschichte der deutschen Reichsverfassung in Mittelalter und Neuzeit, Vol. 2, Tübingen: J.G.B. Mohr (Paul Siebeck), 2nd ed. 1913.

Zschunke, Peter, Konfession und Alltag in Oppenheim, Wiesbaden: Franz Steiner, 1984. 


\section{A Appendix: Data description}

\section{A.1 City size dataset}

\begin{tabular}{|c|c|}
\hline Variable & Description and Source \\
\hline Augustinian monasteries p.c. & $\begin{array}{l}\text { Number of Augustinian monasteries in existence around } 1517 \\
\text { within } 5 \mathrm{~km} \text { from the city center (great circle distance), divided } \\
\text { by total population in } 1500 \text { (in } 1000 \text { 's). If there is no popula- } \\
\text { tion figure for a city in } 1500 \text {, city size is assumed to equal } 500 \text {. } \\
\text { Source: Jürgensmeier and Schwerdtfeger, eds (2005-2008). }\end{array}$ \\
\hline City age & $\begin{array}{l}\text { Year of official incorporation as a city. Source: Keyser (1939- } \\
\text { 1974). }\end{array}$ \\
\hline City size & $\begin{array}{l}\text { Population of a city in thousands. Missing values are not im- } \\
\text { puted, unless otherwise noted. Source: Bairoch et al. (1988) } \\
\text { for the years until 1850. Official statistics (German Empire: } \\
\text { Statistik des Deutschen Reiches, various vols.; Austria-Hungary: } \\
\text { Statistisches Jahrbuch, herausgegeben von der K. K. Statistischen } \\
\text { Central-Commission, various vols.) for the years after } 1850 \text {. }\end{array}$ \\
\hline Distance to Atlantic ports & $\begin{array}{l}\text { Minimum great circle distance of a city to the Atlantic sea- } \\
\text { ports of either Hamburg or Bremen, measured in } 100 \text { 's of km. } \\
\text { Source: own calculations. }\end{array}$ \\
\hline Distance to Coal & $\begin{array}{l}\text { Minimum great circle distance of a city to any of the coal min- } \\
\text { ing fields active in Germany at any time, measured in 100's } \\
\text { of km. Sources: Geologische Karte der Bundesrepublik Deutsch- } \\
\text { land 1:1 } 000 \text { 000 (Bundesanstalt für Geowissenschaften und } \\
\text { Rohstoffe, 1993), Wikipedia. Own calculations. }\end{array}$ \\
\hline Distance to Geneva & $\begin{array}{l}\text { Great circle distance of a city to Geneva, measured in } 100 \text { 's of } \\
\mathrm{km} \text {. Source: own calculations. }\end{array}$ \\
\hline Distance to Wittenberg & $\begin{array}{l}\text { Great circle distance of a city to Wittenberg, measured in } 100 \text { 's } \\
\text { of } \mathrm{km} \text {. Source: own calculations. }\end{array}$ \\
\hline Distance to Zurich & $\begin{array}{l}\text { Great circle distance of a city to Zurich, measured in } 100 \text { 's of } \\
\mathrm{km} \text {. Source: own calculations. }\end{array}$ \\
\hline Ecclesiastical & $\begin{array}{l}\text { Binary, } 1 \text { if city belongs to an ecclesiastical territory. Source: } \\
\text { Keyser (1939-1974). }\end{array}$ \\
\hline Hanseatic & $\begin{array}{l}\text { Binary, } 1 \text { if city belonged to the Hanseatic league in the 15th } \\
\text { century. Source: Hammel-Kiesow (2000). }\end{array}$ \\
\hline Latitude & Latitude of the city in degrees. Source: passim. \\
\hline Longitude & Longitude of the city in degrees. Source: passim. \\
\hline
\end{tabular}

Continued on next page 


\begin{tabular}{|c|c|}
\hline Variable & Description and Source \\
\hline Number of monasteries p.c. & $\begin{array}{l}\text { Number of monasteries (not belonging to mendicant orders) in } \\
\text { existence around } 1517 \text { within } 5 \mathrm{~km} \text { from the city center (great } \\
\text { circle distance), divided by total population in } 1500 \text { (in } 1000 \text { 's). } \\
\text { If there is no population figure for a city in } 1500 \text {, city size is as- } \\
\text { sumed to equal } 500 \text {. Source: Jürgensmeier and Schwerdtfeger, } \\
\text { eds (2005-2008). }\end{array}$ \\
\hline Protestant & $\begin{array}{l}\text { Binary, } 1 \text { if Protestantism is the only or dominant religious de- } \\
\text { nomination in a territory, as resulting from the normal year } \\
\text { 1624. Sources: Schindling and Ziegler, eds (1993) and Keyser } \\
\text { (1939-1974). For years prior to 1600, "Protestantism" is coded } \\
\text { as } 1 \text { in city } i \text { if } i \text { was Protestant in 1600. }\end{array}$ \\
\hline $\begin{array}{l}\text { Contribution to the Reichsma- } \\
\text { trikel }\end{array}$ & $\begin{array}{l}\text { Total contribution of a territory to the expenditures of the Em- } \\
\text { pire (in guilders). I used the conventional correspondences of } \\
1 \text { footed soldier }=4 \text { guilders and } 1 \text { cavalry soldier }=12 \text { guilders } \\
\text { to translate the single values into a total contribution. Sources: } \\
\text { Zeumer, ed (1913), Schmidt (1984, p. 332). }\end{array}$ \\
\hline River & Location on a navigable river. Source: Kunz, ed (1999). \\
\hline Trend & Linear time trend, starting in 1517 . Measured in centuries. \\
\hline Urban population in a territory & $\begin{array}{l}\text { Total population of all cities listed in Bairoch et al. (1988) be- } \\
\text { longing to a given territory; definition of a "territory" is dis- } \\
\text { cussed on page } 16 \text {, footnote } 18 \text { and is time-invariant. Missing } \\
\text { values are not imputed. }\end{array}$ \\
\hline
\end{tabular}

\section{A.2 Prussian manufacturing census, 1821}

\begin{tabular}{|c|c|}
\hline Variable & Description \\
\hline Business tax p.c. & $\begin{array}{l}\text { Tax revenue from business enterprises (Gewerbesteuer) per inhabi- } \\
\text { tant, } 1821 \text { (in Thaler) }\end{array}$ \\
\hline Fire insurance p.c. & $\begin{array}{l}\text { Total value of buildings insured by the local fire insurance com- } \\
\text { pany (Feuersozietät) per inhabitant, } 1821 \text { (in Thaler) }\end{array}$ \\
\hline$\%$ Houses with stonework & $\begin{array}{l}\text { Buildings with masonry outer walls (as opposed to half-timbered } \\
\text { or timber) as percentage of total buildings, } 1816\end{array}$ \\
\hline $\begin{array}{l}\% \text { Houses with shingled } \\
\text { roofs }\end{array}$ & $\begin{array}{l}\text { Buildings with shingled (metal, stone or clay shingles) roofs (as } \\
\text { opposed to wooden shingles or thatchered) as percentage of total } \\
\text { buildings, } 1816\end{array}$ \\
\hline Looms p.c. & Number of looms in 1819 per inhabitant (population figures: 1816) \\
\hline Merchants p.c. & $\begin{array}{l}\text { Number of merchants (mit kaufmännischen Rechten), grocers, and } \\
\text { peddlers in } 1819 \text { per inhabitant (population figures: 1816) }\end{array}$ \\
\hline Teacher-to-student ratio & $\begin{array}{l}\text { Number of teachers per student in private and public elementary } \\
\text { schools, } 1816\end{array}$ \\
\hline
\end{tabular}

Source (for all variables): Krug and Mützell (1825) 


\section{B Figures and Tables}

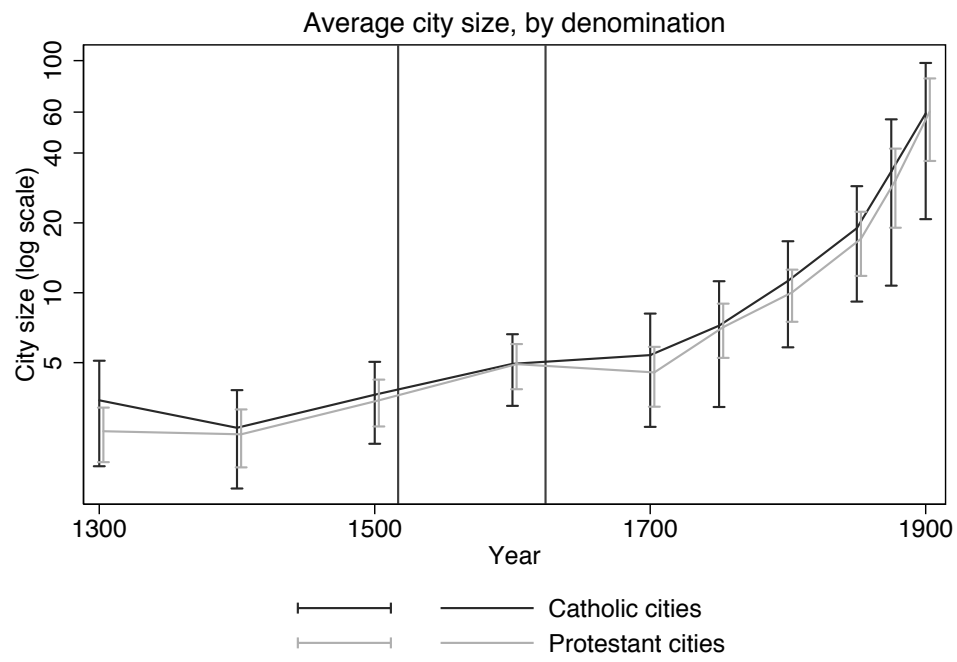

Figure 1: Average population of cities, by denomination. Population figures in thousands. Vertical bars indicate the onset of the Reformation (1517) and the "normal year" set by the Peace of Westphalia (1624). Capped spikes denote 95\% confidence intervals around the sample average. Population is assumed to be equal to 500 inhabitants if the actual value is missing in Bairoch et al. (1988). 


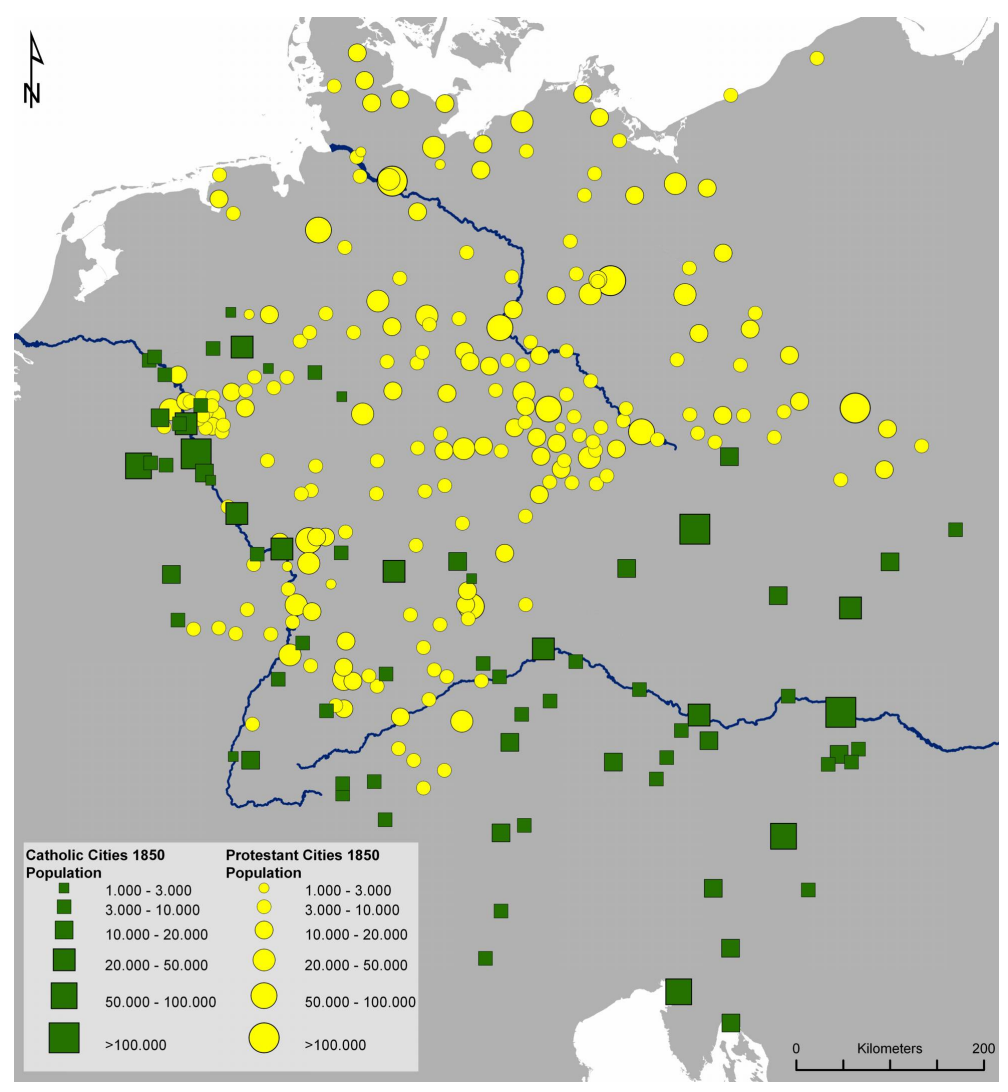

Figure 2: Cities in the dataset and their populations in 1850
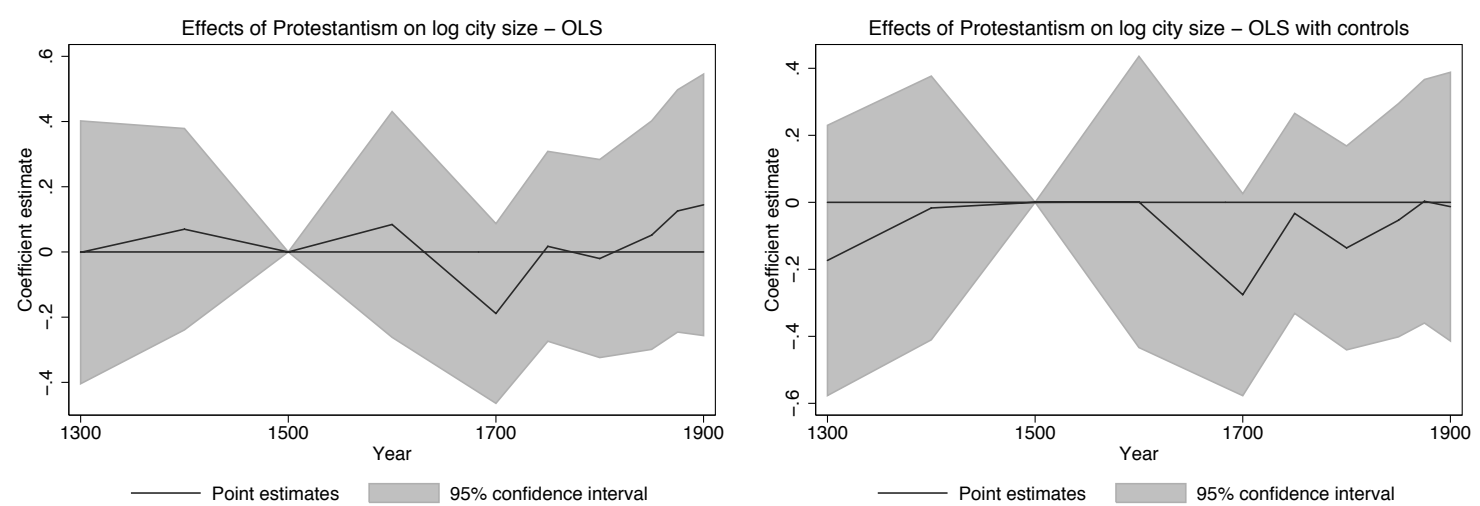

Figure 3: Estimated coefficients and 95\% confidence intervals. Results from the baseline OLS estimates in Table 5, columns (1) and (3), panel C. 


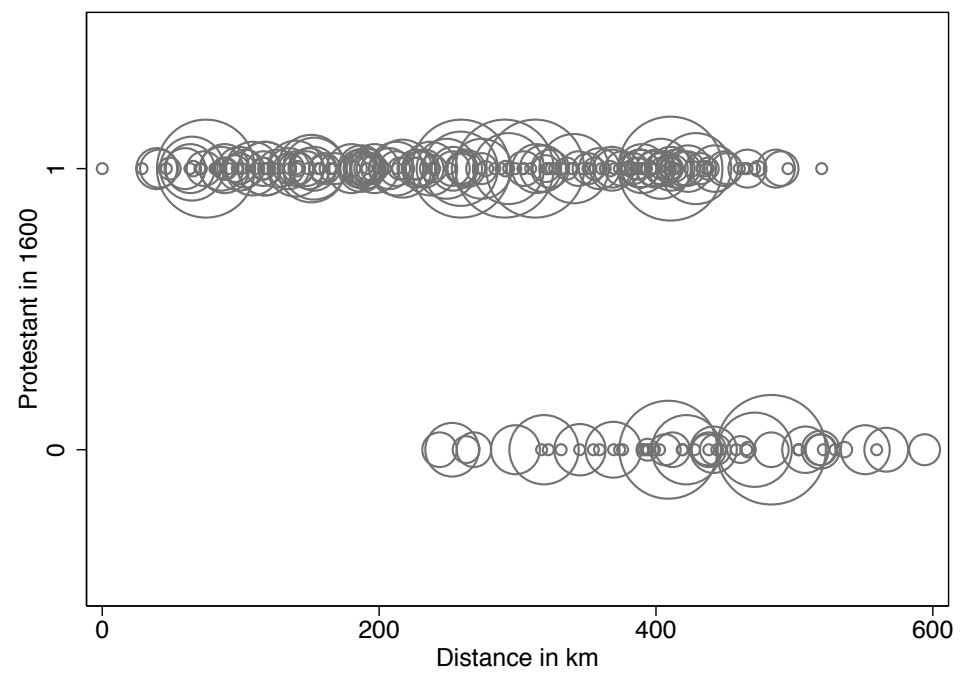

Figure 4: Protestantism in 1600 and distance to Wittenberg for cities in the dataset. Circle size proportional to city population in 1500.
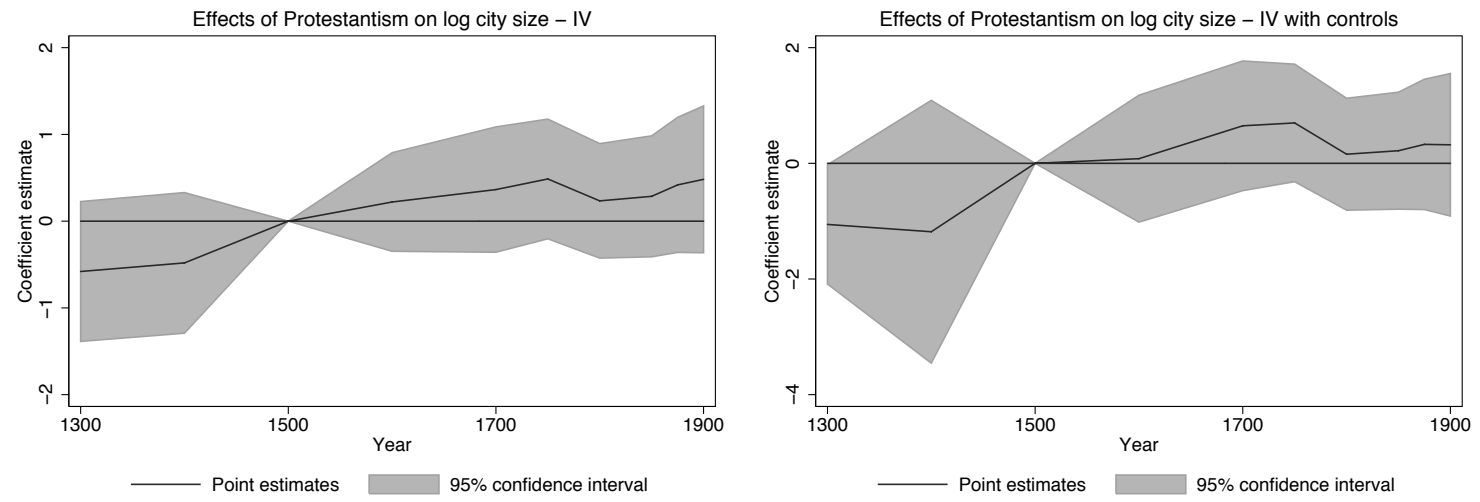

Figure 5: Estimated coefficients and 95\% confidence intervals. Results from the baseline IV estimates in Table 9, columns (1) and (3), panel C. 


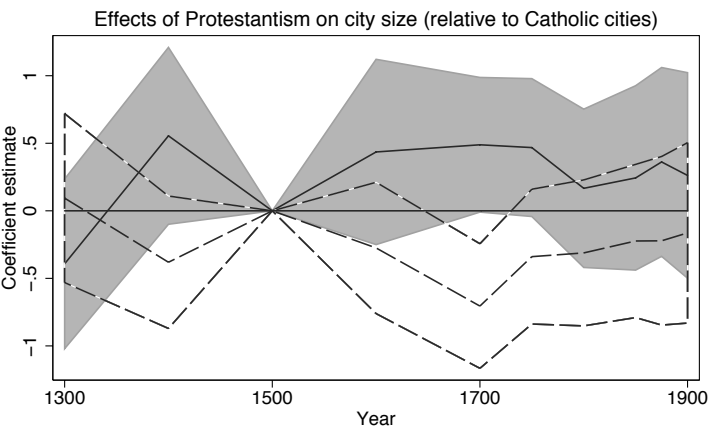

- - Point est./95\% c.i. - Cities close to Atlantic

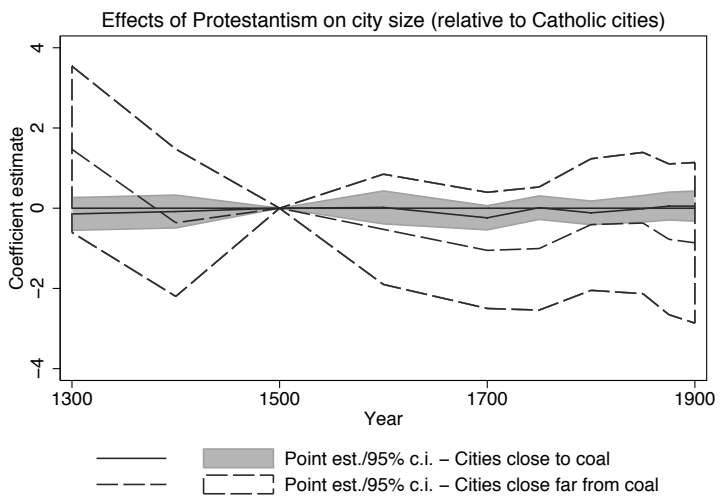

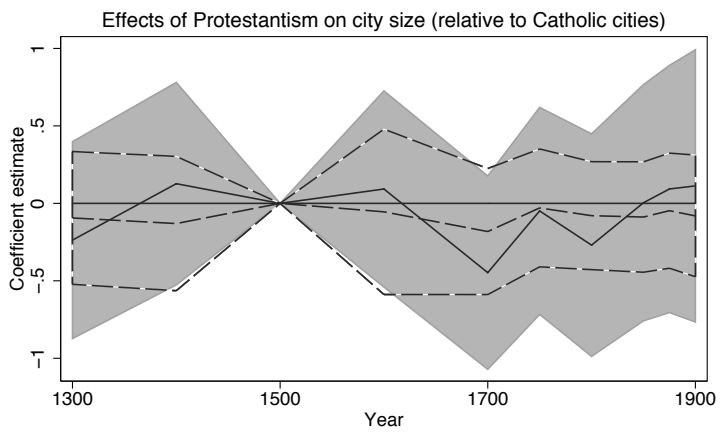

$-\square$ Point est./95\% c.i. - Cities on a river/port

Effects of Protestantism on city size (relative to Catholic cities)

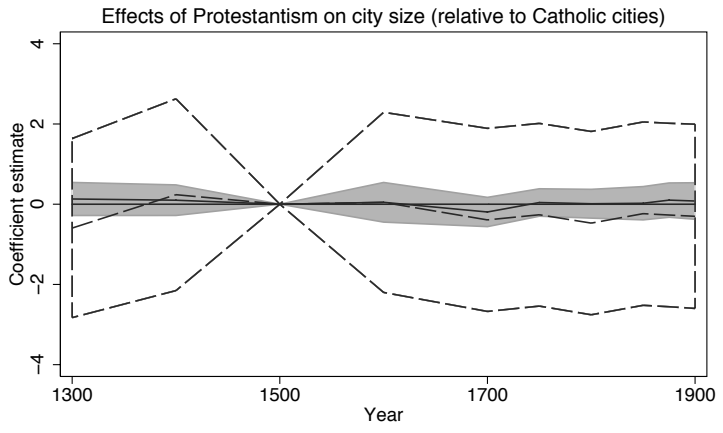

- - —ニこ Point est./95\% c.i. - Cities with many monasteries

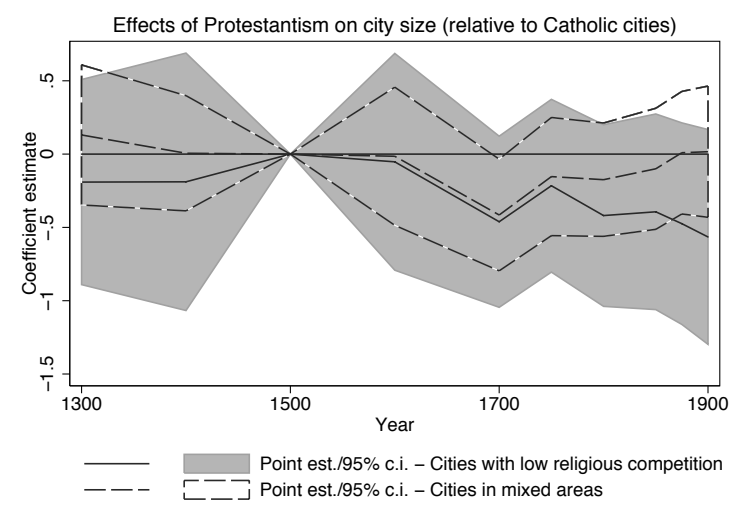

Figure 6: Estimated effects and 95\% confidence intervals. Results from the OLS estimates of section 6, equation (7). 
Table 1: Homogeneity of religious affiliation after 1624

\begin{tabular}{lrrrr}
\hline Territory & $\begin{array}{r}\text { Population } \\
(1849)\end{array}$ & $\begin{array}{r}\text { Religion } \\
\text { (after 1624) }\end{array}$ & $\begin{array}{r}\text { \% Prot. } \\
(1849)\end{array}$ & $\begin{array}{r}\text { \% Cath. } \\
(1849)\end{array}$ \\
\hline \hline Prince-Bishopric of Münster & 329081 & Cat & 4.3 & 94.9 \\
Duchy of Westphalia & 191425 & Cat & 8.7 & 90.0 \\
Prince-Bishoprics of Paderborn and Corvey Abbey & 160404 & Cat & 4.7 & 92.9 \\
Vest Recklinghausen & 46940 & Cat & 1.3 & 98.2 \\
\hline County of Mark & 305182 & Pro & 78.1 & 21.0 \\
Principality of Minden and County of Ravensberg & 260096 & Pro & 97.2 & 2.1 \\
Principality of Siegen & 44885 & Pro & 82.3 & 17.5 \\
Counties of Wittgenstein-Berleburg and W.-Hohenstein & 21463 & Pro & 94.1 & 3.9 \\
Free Imperial city of Dortmund & 10515 & Pro & 71.1 & 27.1 \\
Lippstadt & 4845 & Pro & 40.5 & 58.0 \\
\hline Counties of Tecklenburg and Lingen & 42123 & Pro / Cat & 55.8 & 43.6 \\
\hline
\end{tabular}

Source: Reekers (1964).

Table 2: Summary statistics

\begin{tabular}{rrrrrrr}
\hline & N. Obs. & Mean & Std.dev. & Catholic cities & Protestant cities & Difference \\
\hline \hline City size in 1300 & 80 & 8400 & 8577 & 11579 & 7410 & $4169^{*}$ \\
City size in 1500 & 126 & 6984 & 7183 & 8960 & 6495 & 2465 \\
City size in 1800 & 268 & 10584 & 20868 & 12137 & 10002 & 2135 \\
City size in 1900 & 271 & 60216 & 169798 & 64166 & 58760 & 5406 \\
\hline Latitude & 272 & 50.82 & 1.69 & 49.49 & 51.17 & $-1.68^{* * *}$ \\
Longitude & 272 & 10.64 & 2.77 & 9.69 & 10.90 & $-1.21^{* * *}$ \\
River & 272 & 0.360 & 0.481 & 0.414 & 0.346 & 0.068 \\
Distance to Wittenberg & 272 & 295.6 & 137.1 & 422.3 & 261.3 & $161.1^{* * *}$ \\
Distance to Atlantic ports & 272 & 335.9 & 166.5 & 445.3 & 306.3 & $139.0^{* * *}$ \\
\hline Date of foundation & 272 & 977.5 & 352.5 & 766.7 & 1034.6 & $-267.9^{* * *}$ \\
Free city & 272 & 0.140 & 0.347 & 0.121 & 0.145 & -0.024 \\
Hansa & 272 & 0.099 & 0.300 & 0.052 & 0.112 & -0.060 \\
Ecclesiastical & 272 & 0.121 & 0.327 & 0.397 & 0.047 & $0.350^{* * *}$ \\
Number of monasteries p.c. & 272 & 1.134 & 1.859 & 2.019 & 0.894 & $1.125^{* * *}$ \\
Augustinian monasteries p.c. & 272 & 0.112 & 0.429 & 0.187 & 0.092 & 0.095 \\
\hline *: Difference significant at 10\%; ${ }^{* *}: 5 \% ; * * *: 1 \%$. & & & &
\end{tabular}




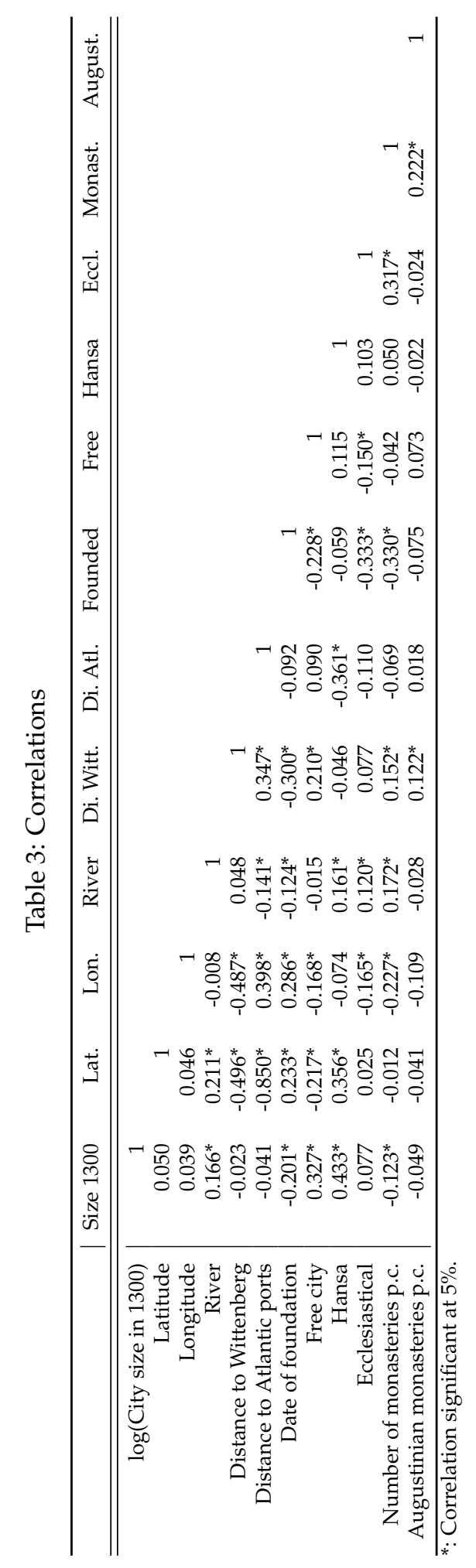




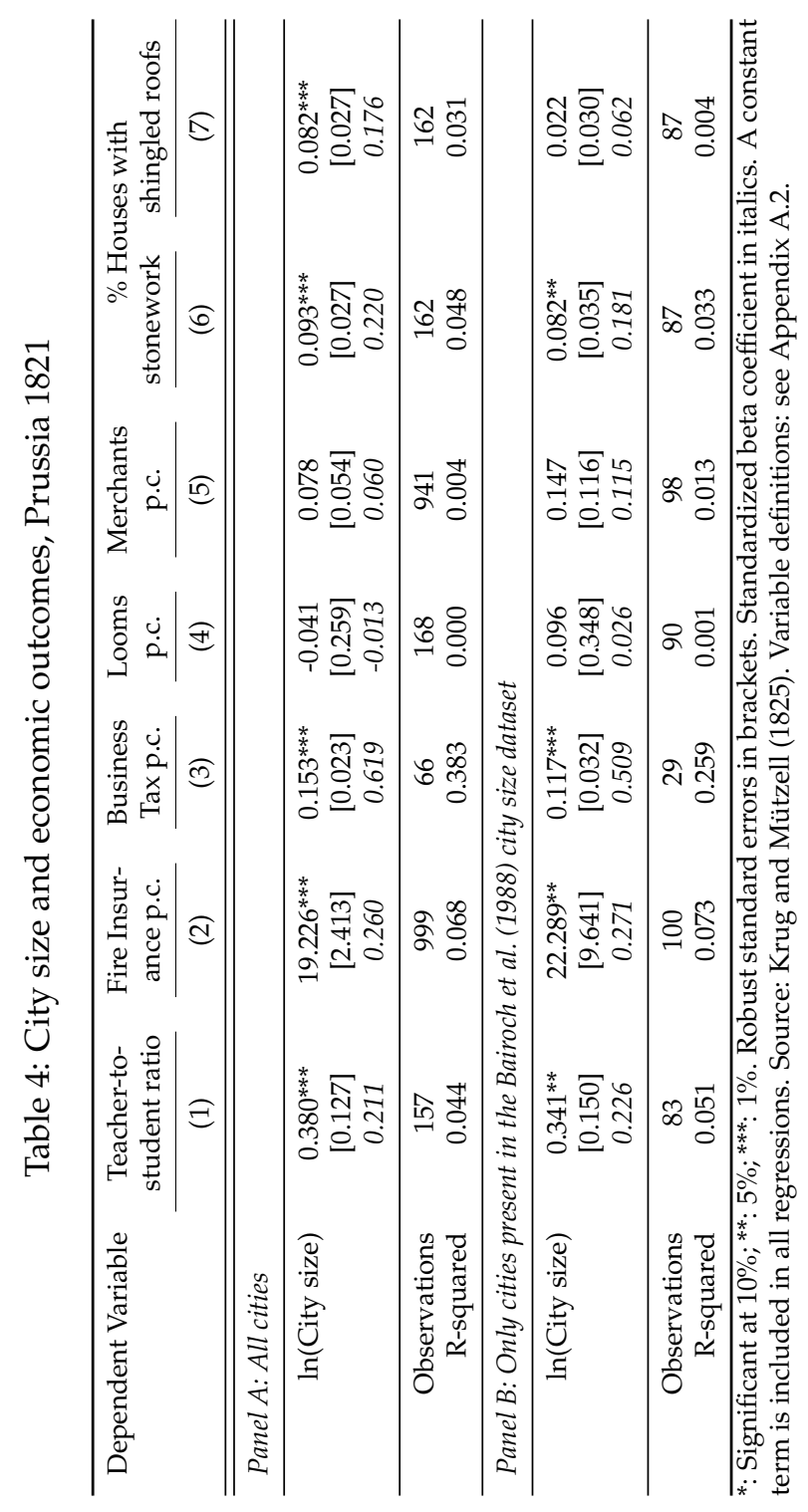


Table 5: OLS estimation

\begin{tabular}{|c|c|c|c|c|c|c|}
\hline \multirow[t]{2}{*}{ Dependent Variable } & \multicolumn{3}{|c|}{$\ln ($ City size $)$} & \multicolumn{3}{|c|}{$\ln$ (Urban pop. in a territory) } \\
\hline & (1) & (2) & (3) & (4) & (5) & (6) \\
\hline \multicolumn{7}{|l|}{ Panel A: Differences-in-Differences } \\
\hline Protestant $\cdot$ Post1517 & $\begin{array}{c}0.022 \\
{[0.152]}\end{array}$ & $\begin{array}{c}-0.042 \\
{[0.153]}\end{array}$ & $\begin{array}{c}-0.012 \\
{[0.153]}\end{array}$ & $\begin{array}{c}-0.058 \\
{[0.199]}\end{array}$ & $\begin{array}{c}-0.159 \\
{[0.207]}\end{array}$ & $\begin{array}{c}-0.037 \\
{[0.151]}\end{array}$ \\
\hline \multicolumn{7}{|l|}{ Panel B: Structured setup } \\
\hline Protestant $\cdot$ Post1517 & $\begin{array}{c}-0.110 \\
{[0.202]}\end{array}$ & $\begin{array}{c}-0.113 \\
{[0.205]}\end{array}$ & $\begin{array}{c}-0.139 \\
{[0.273]}\end{array}$ & $\begin{array}{c}-0.140 \\
{[0.163]}\end{array}$ & $\begin{array}{c}-0.143 \\
{[0.166]}\end{array}$ & $\begin{array}{c}-0.074 \\
{[0.177]}\end{array}$ \\
\hline Protestant $\cdot$ Post $1517 \cdot$ Trend & $\begin{array}{c}0.054 \\
{[0.078]}\end{array}$ & $\begin{array}{c}0.025 \\
{[0.088]}\end{array}$ & $\begin{array}{c}0.027 \\
{[0.099]}\end{array}$ & $\begin{array}{c}0.069 \\
{[0.070]}\end{array}$ & $\begin{array}{c}0.027 \\
{[0.073]}\end{array}$ & $\begin{array}{c}0.023 \\
{[0.063]}\end{array}$ \\
\hline $\mathrm{p}$-value for joint significance Protestant & 0.789 & 0.824 & 0.837 & 0.578 & 0.683 & 0.904 \\
\hline \multicolumn{7}{|l|}{ Panel C: Fully flexible setup } \\
\hline Protestant · Year 1300 & $\begin{array}{c}-0.001 \\
{[0.206]}\end{array}$ & $\begin{array}{c}-0.015 \\
{[0.185]}\end{array}$ & $\begin{array}{c}-0.173 \\
{[0.206]}\end{array}$ & $\begin{array}{c}0.175 \\
{[0.211]}\end{array}$ & $\begin{array}{c}0.149 \\
{[0.225]}\end{array}$ & $\begin{array}{c}-0.064 \\
{[0.206]}\end{array}$ \\
\hline Protestant · Year 1400 & $\begin{array}{c}0.070 \\
{[0.158]}\end{array}$ & $\begin{array}{c}0.009 \\
{[0.172]}\end{array}$ & $\begin{array}{c}-0.017 \\
{[0.201]}\end{array}$ & $\begin{array}{c}0.232 \\
{[0.157]}\end{array}$ & $\begin{array}{c}0.181 \\
{[0.155]}\end{array}$ & $\begin{array}{c}0.161 \\
{[0.152]}\end{array}$ \\
\hline Protestant · Year 1600 & $\begin{array}{c}0.084 \\
{[0.177]}\end{array}$ & $\begin{array}{c}0.003 \\
{[0.175]}\end{array}$ & $\begin{array}{c}0.001 \\
{[0.222]}\end{array}$ & $\begin{array}{c}0.044 \\
{[0.145]}\end{array}$ & $\begin{array}{c}-0.067 \\
{[0.150]}\end{array}$ & $\begin{array}{c}0.011 \\
{[0.152]}\end{array}$ \\
\hline Protestant · Year 1700 & $\begin{array}{c}-0.189 \\
{[0.141]}\end{array}$ & $\begin{array}{l}-0.237^{*} \\
{[0.128]}\end{array}$ & $\begin{array}{l}-0.276^{*} \\
{[0.154]}\end{array}$ & $\begin{array}{c}-0.223 \\
{[0.152]}\end{array}$ & $\begin{array}{c}-0.245 \\
{[0.153]}\end{array}$ & $\begin{array}{c}-0.213 \\
{[0.178]}\end{array}$ \\
\hline Protestant · Year 1750 & $\begin{array}{c}0.017 \\
{[0.149]}\end{array}$ & $\begin{array}{c}0.014 \\
{[0.132]}\end{array}$ & $\begin{array}{c}-0.033 \\
{[0.152]}\end{array}$ & $\begin{array}{c}0.094 \\
{[0.177]}\end{array}$ & $\begin{array}{c}0.024 \\
{[0.184]}\end{array}$ & $\begin{array}{c}0.089 \\
{[0.196]}\end{array}$ \\
\hline Protestant · Year 1800 & $\begin{array}{c}-0.020 \\
{[0.155]}\end{array}$ & $\begin{array}{c}-0.110 \\
{[0.148]}\end{array}$ & $\begin{array}{c}-0.136 \\
{[0.155]}\end{array}$ & $\begin{array}{c}-0.002 \\
{[0.187]}\end{array}$ & $\begin{array}{c}-0.105 \\
{[0.198]}\end{array}$ & $\begin{array}{c}-0.056 \\
{[0.177]}\end{array}$ \\
\hline Protestant · Year 1850 & $\begin{array}{c}0.052 \\
{[0.179]}\end{array}$ & $\begin{array}{c}-0.039 \\
{[0.185]}\end{array}$ & $\begin{array}{c}-0.053 \\
{[0.178]}\end{array}$ & $\begin{array}{c}0.084 \\
{[0.195]}\end{array}$ & $\begin{array}{c}-0.044 \\
{[0.210]}\end{array}$ & $\begin{array}{c}0.015 \\
{[0.187]}\end{array}$ \\
\hline Protestant · Year 1875 & $\begin{array}{c}0.126 \\
{[0.190]}\end{array}$ & $\begin{array}{c}0.008 \\
{[0.188]}\end{array}$ & $\begin{array}{c}0.003 \\
{[0.185]}\end{array}$ & $\begin{array}{c}0.110 \\
{[0.209]}\end{array}$ & $\begin{array}{c}-0.062 \\
{[0.219]}\end{array}$ & $\begin{array}{c}-0.001 \\
{[0.196]}\end{array}$ \\
\hline Protestant · Year 1900 & $\begin{array}{c}0.144 \\
{[0.205]}\end{array}$ & $\begin{array}{c}0.011 \\
{[0.201]}\end{array}$ & $\begin{array}{l}-0.013 \\
{[0.205]}\end{array}$ & $\begin{array}{c}0.186 \\
{[0.226]}\end{array}$ & $\begin{array}{l}-0.014 \\
{[0.233]}\end{array}$ & $\begin{array}{c}0.037 \\
{[0.212]}\end{array}$ \\
\hline $\begin{array}{l}\text { p-value for joint significance Protestant } \\
\text { p-value for joint significance Latitude } \\
\text { p-value for joint significance Longitude }\end{array}$ & 0.017 & $\begin{array}{c}0.045 \\
0.010 \\
0.0023\end{array}$ & 0.010 & 0.062 & $\begin{array}{l}0.079 \\
0.082 \\
0.053\end{array}$ & 0.098 \\
\hline p-value for joint significance Dist. to Atlantic & & & 0.027 & & & 0.153 \\
\hline $\mathrm{p}$-value for joint significance City size in 1300 & & & 0.000 & & & 0.000 \\
\hline Controls Latitude & $\mathrm{N}$ & Y & $\mathrm{N}$ & $\mathrm{N}$ & Y & $\mathrm{N}$ \\
\hline Controls Longitude & $\mathrm{N}$ & $\mathrm{Y}$ & $\mathrm{N}$ & $\mathrm{N}$ & $\mathrm{Y}$ & $\mathrm{N}$ \\
\hline Controls Distance to Atlantic ports & $\mathrm{N}$ & $\mathrm{N}$ & $\mathrm{Y}$ & $\mathrm{N}$ & $\mathrm{N}$ & $\mathrm{Y}$ \\
\hline Controls City size in 1300 & $\mathrm{~N}$ & $\mathrm{~N}$ & Y & $\mathrm{N}$ & $\mathrm{N}$ & Y \\
\hline $\begin{array}{r}\text { Observations } \\
\text { Number of cities/territories }\end{array}$ & $\begin{array}{c}1876 \\
272\end{array}$ & $\begin{array}{c}1876 \\
272\end{array}$ & $\begin{array}{c}1876 \\
272\end{array}$ & $\begin{array}{l}986 \\
128\end{array}$ & $\begin{array}{l}986 \\
128\end{array}$ & $\begin{array}{l}986 \\
128\end{array}$ \\
\hline
\end{tabular}

*: Significant at $10 \% ;{ }^{* *}: 5 \% ; * * *: 1 \%$. All regressions contain a full set of city and year fixed effects. Regressions in Panel B also include the pre-treatment interaction terms "Protestant · Year 1300" and "Protestant - Year 1400" (coefficients not reported). Control variables are entered as a full set of control · year dummy interactions in all three panels. P-values refer to a joint test significance of all coefficients relating to the post-Reformation period (interactions of respective variable with year dummies, 1600 and onwards) and are reported only for the setup of Panel C. Robust standard errors, clustered by territory, in brackets. 


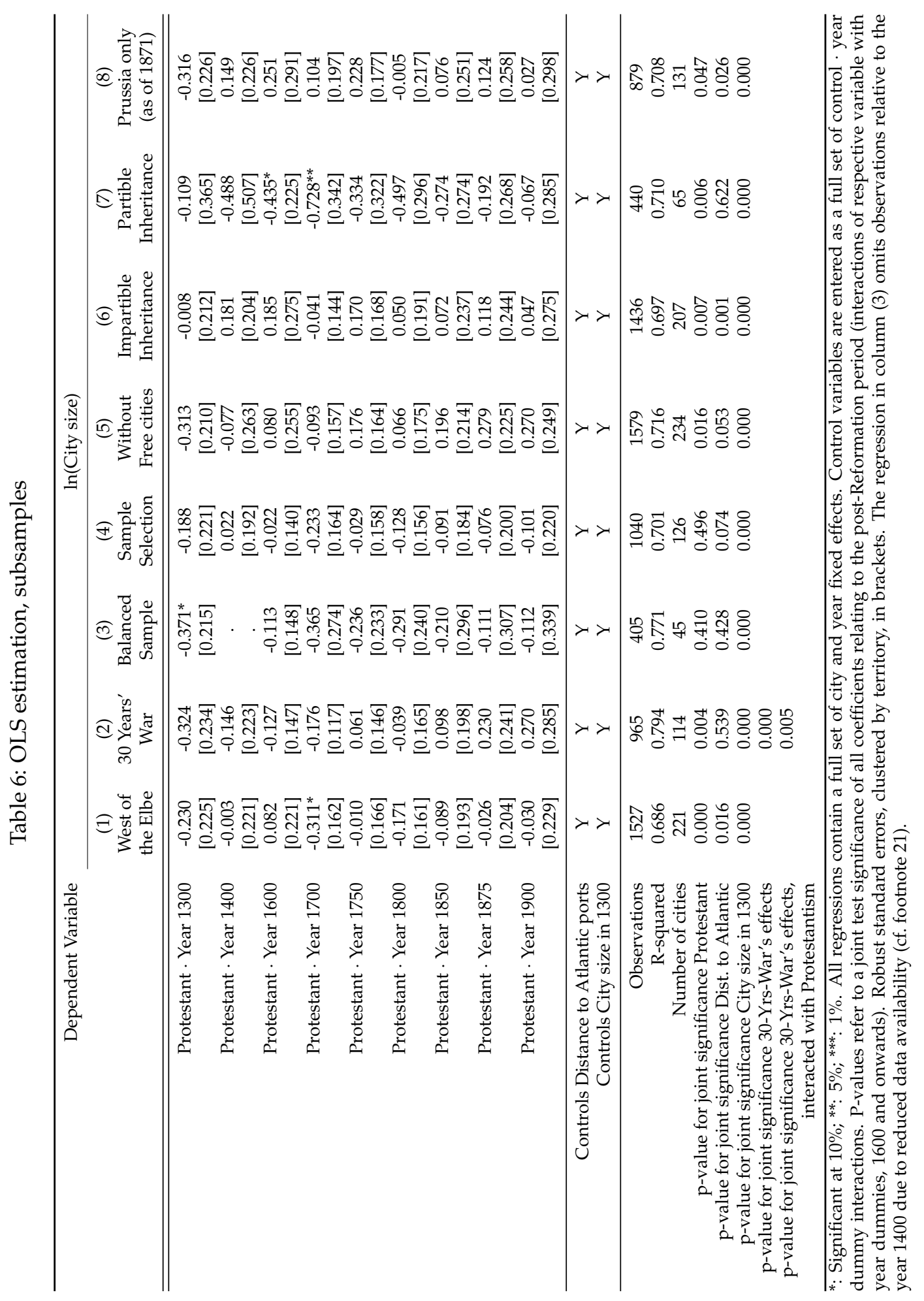


Table 7: Calvinist vs. Lutheran

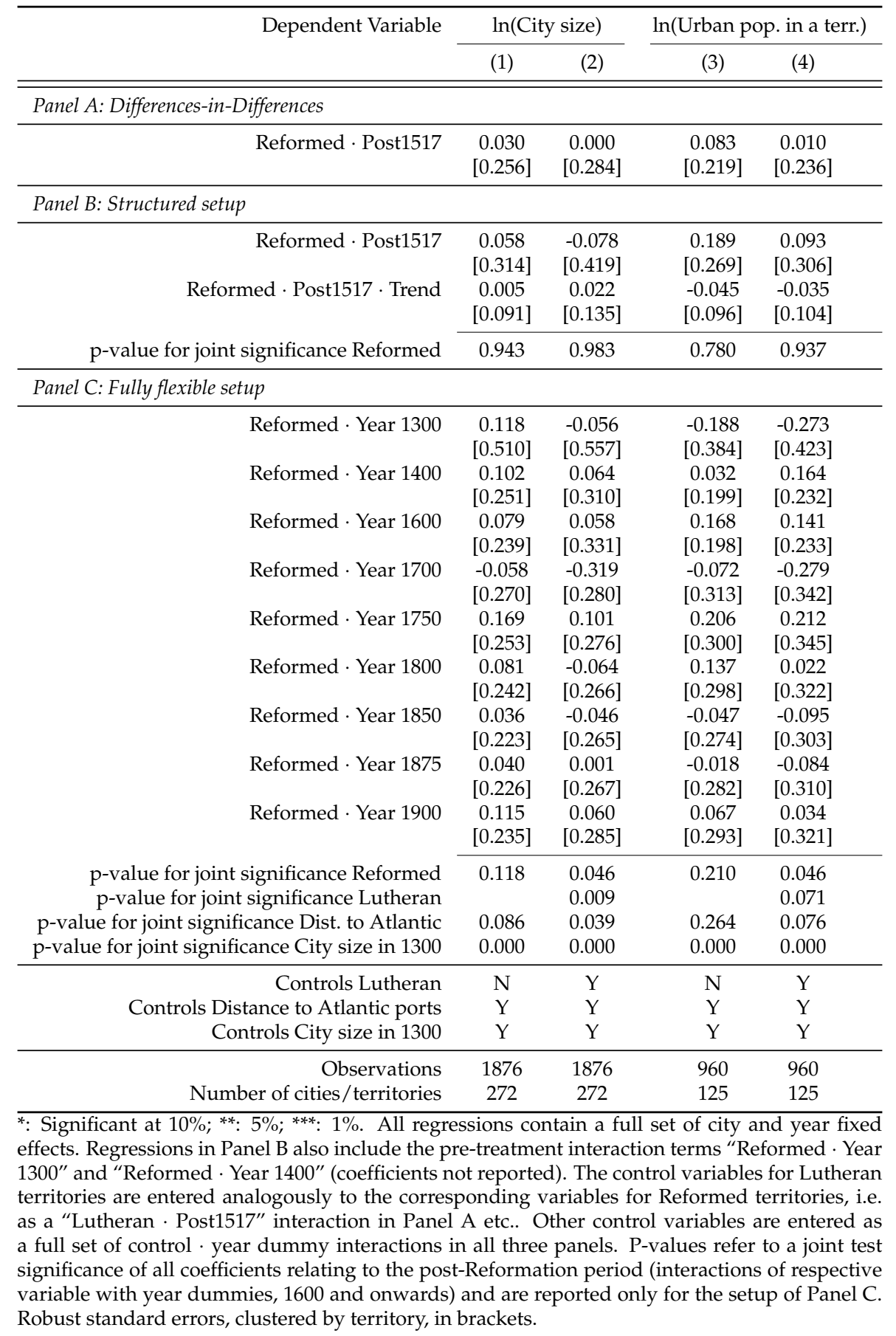


Table 8: Determinants of adoption of Protestantism

\begin{tabular}{|c|c|c|c|c|c|c|}
\hline \multirow[t]{2}{*}{ Dependent Variable } & \multicolumn{4}{|c|}{ City Protestant in 1600} & \multicolumn{2}{|c|}{ Terr. Protestant in 1600} \\
\hline & (1) & (2) & (3) & (4) & (5) & (6) \\
\hline \multirow[t]{2}{*}{ Distance to Wittenberg } & $-0.158^{* * *}$ & $-0.154^{* * *}$ & $-0.183^{* * *}$ & $-0.199^{* * *}$ & $-0.129^{* * *}$ & $-0.155^{* *}$ \\
\hline & [0.029] & [0.031] & [0.037] & [0.035] & [0.024] & [0.062] \\
\hline \multirow[t]{2}{*}{ Ecclesiastical } & & $-0.415^{* * *}$ & $-0.422^{* * *}$ & $-0.341^{* * *}$ & & $-0.601^{* * *}$ \\
\hline & & [0.091] & [0.099] & [0.117] & & [0.115] \\
\hline \multirow[t]{2}{*}{ Distance to Geneva } & & & 0.003 & & & \\
\hline & & & {$[0.191]$} & & & \\
\hline \multirow[t]{2}{*}{ Distance to Zurich } & & & -0.051 & & & \\
\hline & & & {$[0.183]$} & & & \\
\hline \multirow[t]{2}{*}{ River } & & & & $0.151^{* * *}$ & & 0.123 \\
\hline & & & & {$[0.055]$} & & [0.098] \\
\hline \multirow[t]{2}{*}{ Latitude } & & & & 0.001 & & 0.007 \\
\hline & & & & {$[0.034]$} & & {$[0.033]$} \\
\hline \multirow[t]{2}{*}{ Longitude } & & & & -0.040 & & -0.009 \\
\hline & & & & {$[0.025]$} & & [0.035] \\
\hline \multirow[t]{2}{*}{ Date of foundation } & & & & 0.095 & & 0.177 \\
\hline & & & & [0.083] & & {$[0.205]$} \\
\hline \multirow[t]{2}{*}{$\ln$ (Total urban population in 1500 ) } & & & & $-0.045^{* *}$ & & -0.006 \\
\hline & & & & {$[0.020]$} & & {$[0.075]$} \\
\hline \multirow[t]{2}{*}{ Hansa } & & & & 0.051 & & -0.225 \\
\hline & & & & [0.103] & & {$[0.150]$} \\
\hline \multirow[t]{2}{*}{ Free Imperial City } & & & & $0.374^{* * *}$ & & 0.142 \\
\hline & & & & [0.105] & & [0.096] \\
\hline \multirow[t]{2}{*}{ Number of monasteries } & & & & $-0.032^{*}$ & & 0.006 \\
\hline & & & & {$[0.017]$} & & {$[0.045]$} \\
\hline \multirow[t]{2}{*}{ Augustinian monasteries } & & & & -0.026 & & -0.177 \\
\hline & & & & {$[0.064]$} & & [0.206] \\
\hline \multirow[t]{2}{*}{ Contribution to the Reichsmatrikel } & & & & & & -0.078 \\
\hline & & & & & & [0.115] \\
\hline \multirow{4}{*}{$\begin{array}{r}\text { Contribution to the Reichsmatrikel/ } \\
\text { Total urban population in } 1500 \\
\text { Constant }\end{array}$} & & & & & & -0.057 \\
\hline & & & & & & [0.142] \\
\hline & $1.068^{* * *}$ & $1.109^{* * *}$ & $1.409^{* * *}$ & 1.457 & $1.114^{* * *}$ & 0.983 \\
\hline & [0.078] & [0.081] & [0.497] & [1.833] & [0.066] & [1.819] \\
\hline Observations & 272 & 272 & 272 & 272 & 115 & 75 \\
\hline R-squared & 0.230 & 0.312 & 0.337 & 0.433 & 0.138 & 0.591 \\
\hline
\end{tabular}

*: Significant at $10 \% ;{ }^{* *}: 5 \% ;{ }^{* *}: 1 \%$. Linear probability model (OLS estimation). Robust standard errors in brackets. 
Table 9: Instrumental variables estimates

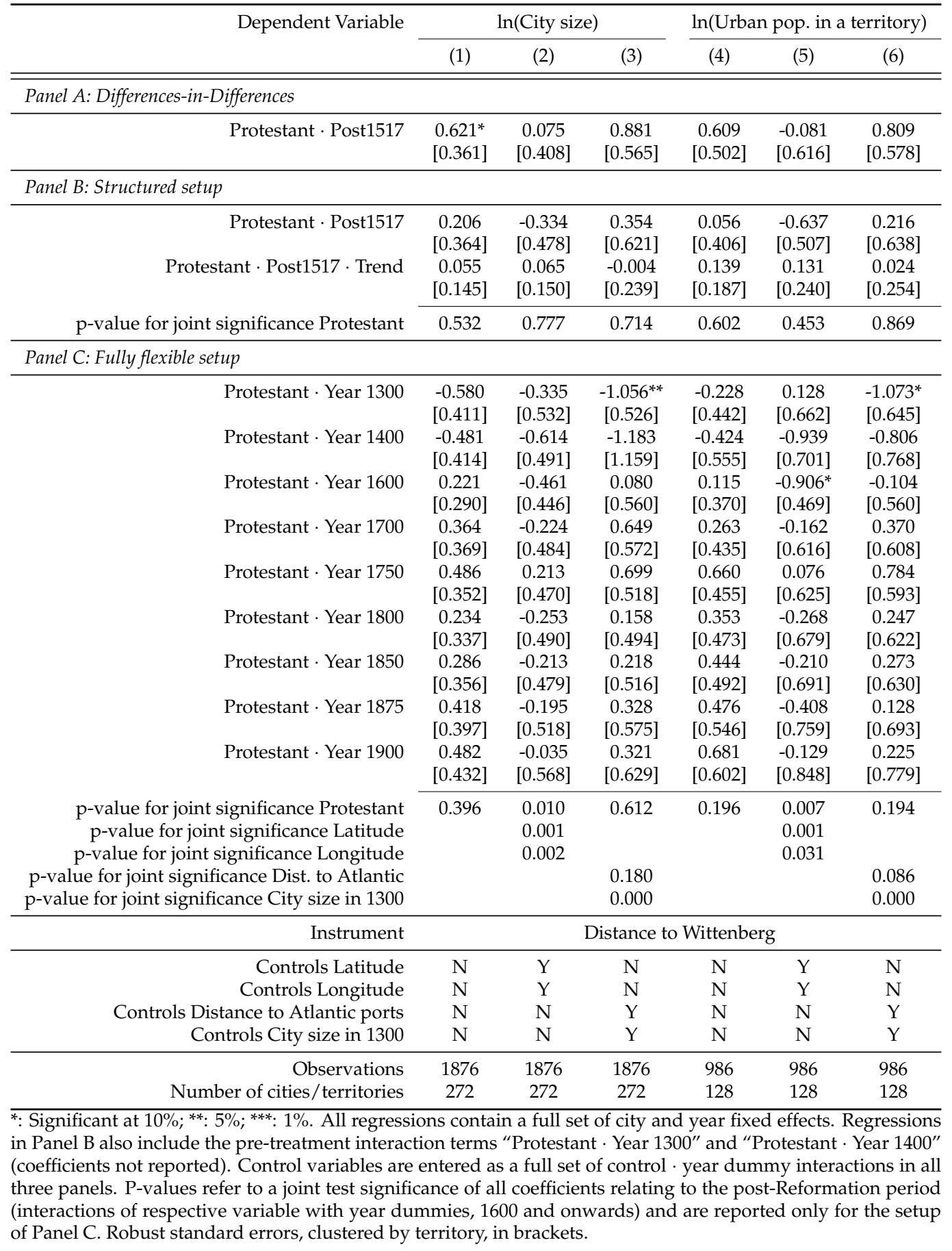




\section{Full results of regressions in section 6}

Table Appendix C.1: Interactions of Protestantism and city characteristics

\begin{tabular}{|c|c|c|c|c|c|c|}
\hline \multirow{3}{*}{\multicolumn{2}{|c|}{$\begin{array}{r}\text { Dependent Variable } \\
\text { Control Variable }\end{array}$}} & \multicolumn{5}{|c|}{$\ln$ (City size) } \\
\hline & & \multirow{2}{*}{$\begin{array}{c}\begin{array}{c}\text { Distance } \\
\text { to Atlantic }\end{array} \\
(1)\end{array}$} & \multirow{2}{*}{$\begin{array}{c}\begin{array}{c}\text { River or } \\
\text { Port }\end{array} \\
(2)\end{array}$} & \multirow{2}{*}{$\begin{array}{c}\begin{array}{c}\text { Distance } \\
\text { to Coal }\end{array} \\
(3)\end{array}$} & \multirow{2}{*}{$\begin{array}{c}\begin{array}{c}\text { Monasteries } \\
\text { (p.c.) }\end{array} \\
(4)\end{array}$} & \multirow{2}{*}{$\begin{array}{c}\begin{array}{c}\text { Religious } \\
\text { Competition }\end{array} \\
(5)\end{array}$} \\
\hline & & & & & & \\
\hline \multicolumn{2}{|r|}{ Protestant - Year 1300} & $\begin{array}{l}-0.533 \\
{[0.445]}\end{array}$ & $\begin{array}{c}-0.094 \\
{[0.219]}\end{array}$ & $\begin{array}{l}-0.608^{*} \\
{[0.354]}\end{array}$ & $\begin{array}{c}0.131 \\
{[0.210]}\end{array}$ & $\begin{array}{c}-0.191 \\
{[0.357]}\end{array}$ \\
\hline \multirow{2}{*}{\multicolumn{2}{|c|}{ Protestant · Year 1400}} & $0.825^{*}$ & -0.130 & -0.002 & 0.100 & -0.189 \\
\hline & & {$[0.446]$} & {$[0.221]$} & [0.411] & [0.194] & {$[0.448]$} \\
\hline \multirow{2}{*}{\multicolumn{2}{|c|}{ Protestant · Year 1600}} & 0.641 & -0.055 & 0.178 & 0.048 & -0.053 \\
\hline & & {$[0.455]$} & {$[0.272]$} & {$[0.337]$} & {$[0.252]$} & [0.377] \\
\hline \multirow{2}{*}{\multicolumn{2}{|c|}{ Protestant - Year 1700}} & $0.834^{* *}$ & -0.182 & -0.005 & -0.194 & -0.461 \\
\hline & & [0.352] & {$[0.208]$} & {$[0.290]$} & [0.186] & [0.298] \\
\hline \multirow{2}{*}{\multicolumn{2}{|c|}{ Protestant · Year 1750}} & $0.701^{*}$ & -0.029 & 0.307 & 0.043 & -0.216 \\
\hline & & [0.367] & [0.194] & [0.273] & [0.175] & [0.301] \\
\hline \multirow{2}{*}{\multicolumn{2}{|c|}{ Protestant · Year 1800}} & 0.305 & -0.080 & -0.031 & 0.012 & -0.419 \\
\hline & & {$[0.426]$} & {$[0.178]$} & {$[0.268]$} & {$[0.183]$} & {$[0.316]$} \\
\hline \multirow{2}{*}{\multicolumn{2}{|c|}{ Protestant - Year 1850}} & 0.378 & -0.088 & 0.090 & 0.024 & -0.394 \\
\hline & & {$[0.484]$} & {$[0.182]$} & {$[0.311]$} & {$[0.212]$} & {$[0.340]$} \\
\hline \multirow{2}{*}{\multicolumn{2}{|c|}{ Protestant · Year 1875}} & 0.530 & -0.047 & 0.293 & 0.102 & -0.475 \\
\hline & & {$[0.500]$} & [0.190] & {$[0.321]$} & {$[0.218]$} & {$[0.351]$} \\
\hline \multirow{2}{*}{\multicolumn{2}{|c|}{ Protestant - Year 1900}} & 0.385 & -0.081 & 0.316 & 0.080 & -0.565 \\
\hline & & {$[0.543]$} & [0.200] & [0.345] & {$[0.232]$} & {$[0.374]$} \\
\hline \multirow{2}{*}{\multicolumn{2}{|c|}{ Control · Year 1300}} & $-0.169^{* *}$ & 0.292 & -0.261 & $0.442^{* * *}$ & 0.263 \\
\hline & & {$[0.084]$} & {$[0.264]$} & {$[0.211]$} & [0.154] & {$[0.581]$} \\
\hline \multirow{2}{*}{\multicolumn{2}{|c|}{ Control · Year 1400}} & 0.101 & -0.157 & 0.186 & $0.329^{* *}$ & -0.211 \\
\hline & & {$[0.082]$} & [0.332] & {$[0.203]$} & [0.165] & [0.677] \\
\hline \multirow{2}{*}{\multicolumn{2}{|c|}{ Control · Year 1600}} & 0.070 & 0.235 & 0.198 & 0.245 & -0.089 \\
\hline & & {$[0.077]$} & [0.343] & {$[0.148]$} & {$[0.162]$} & {$[0.515]$} \\
\hline \multirow{2}{*}{\multicolumn{2}{|c|}{ Control · Year 1700}} & $0.149^{* *}$ & $0.689^{*}$ & 0.241 & 0.234 & -0.674 \\
\hline & & {$[0.065]$} & {$[0.357]$} & [0.147] & {$[0.171]$} & [0.485] \\
\hline \multirow{2}{*}{\multicolumn{2}{|c|}{ Control · Year 1750}} & 0.113 & 0.399 & 0.164 & 0.222 & -0.571 \\
\hline & & {$[0.071]$} & {$[0.367]$} & {$[0.143]$} & [0.164] & {$[0.531]$} \\
\hline \multirow{2}{*}{\multicolumn{2}{|c|}{ Control · Year 1800}} & 0.029 & $0.664^{*}$ & 0.048 & 0.261 & -0.620 \\
\hline & & [0.093] & [0.379] & {$[0.170]$} & [0.165] & [0.595] \\
\hline \multirow{2}{*}{\multicolumn{2}{|c|}{ Control · Year 1850}} & 0.037 & 0.495 & -0.012 & 0.234 & -0.771 \\
\hline & & [0.104] & [0.373] & [0.186] & [0.165] & [0.617] \\
\hline \multirow{2}{*}{\multicolumn{2}{|c|}{ Control · Year 1875}} & 0.038 & 0.472 & 0.009 & 0.231 & -0.977 \\
\hline & & {$[0.110]$} & [0.390] & [0.199] & {$[0.163]$} & {$[0.614]$} \\
\hline & Control · Year 1900 & -0.007 & 0.481 & -0.040 & 0.222 & $-1.103^{*}$ \\
\hline & & {$[0.118]$} & {$[0.413]$} & {$[0.210]$} & {$[0.164]$} & {$[0.622]$} \\
\hline Protestant & t . Control · Year 1300 & 0.110 & -0.143 & 0.364 & -0.181 & 0.643 \\
\hline & & {$[0.114]$} & {$[0.350]$} & {$[0.232]$} & [0.301] & [0.806] \\
\hline Protestant & t. Control · Year 1400 & $-0.211^{* *}$ & 0.257 & -0.063 & 0.034 & 0.390 \\
\hline & & [0.100] & {$[0.388]$} & {$[0.224]$} & {$[0.320]$} & [0.925] \\
\hline Protestant & t. Control · Year 1600 & $-0.161^{*}$ & 0.147 & -0.123 & -0.000 & 0.076 \\
\hline & & [0.096] & [0.381] & [0.165] & [0.299] & [0.743] \\
\hline
\end{tabular}




\begin{tabular}{|c|c|c|c|c|c|}
\hline \multirow{3}{*}{$\begin{array}{r}\text { Dependent Variable } \\
\text { Control Variable }\end{array}$} & \multicolumn{5}{|c|}{$\ln ($ City size $)$} \\
\hline & $\begin{array}{l}\text { Distance } \\
\text { to Atlantic }\end{array}$ & $\begin{array}{l}\text { River or } \\
\text { Port }\end{array}$ & $\begin{array}{l}\text { Distance } \\
\text { to Coal }\end{array}$ & $\begin{array}{l}\text { Monasteries } \\
\text { (p.c.) }\end{array}$ & $\begin{array}{l}\text { Religious } \\
\text { Competition }\end{array}$ \\
\hline & (1) & $(2)$ & (3) & (4) & (5) \\
\hline \multirow[t]{2}{*}{ Protestant · Control · Year 1700} & $-0.270^{* * *}$ & -0.265 & -0.183 & -0.049 & 0.092 \\
\hline & {$[0.088]$} & [0.404] & {$[0.170]$} & [0.309] & [0.597] \\
\hline \multirow[t]{2}{*}{ Protestant $\cdot$ Control $\cdot$ Year 1750} & $-0.182^{*}$ & -0.019 & -0.230 & -0.076 & 0.125 \\
\hline & [0.095] & {$[0.416]$} & {$[0.175]$} & [0.305] & {$[0.720]$} \\
\hline \multirow[t]{2}{*}{ Protestant $\cdot$ Control $\cdot$ Year 1800} & -0.108 & -0.190 & -0.066 & -0.121 & 0.489 \\
\hline & {$[0.110]$} & [0.426] & {$[0.183]$} & [0.309] & {$[0.710]$} \\
\hline \multirow[t]{2}{*}{ Protestant $\cdot$ Control $\cdot$ Year 1850} & -0.105 & 0.092 & -0.081 & -0.065 & 0.587 \\
\hline & [0.119] & {$[0.428]$} & {$[0.201]$} & [0.307] & {$[0.738]$} \\
\hline \multirow[t]{2}{*}{ Protestant $\cdot$ Control $\cdot$ Year 1875} & -0.132 & 0.140 & -0.187 & -0.093 & 0.968 \\
\hline & {$[0.126]$} & [0.448] & {$[0.212]$} & [0.307] & [0.743] \\
\hline \multirow{2}{*}{ Protestant $\cdot$ Control $\cdot$ Year 1900} & -0.096 & 0.194 & -0.207 & -0.095 & 1.163 \\
\hline & [0.135] & {$[0.480]$} & {$[0.226]$} & [0.307] & {$[0.794]$} \\
\hline \multirow{2}{*}{$\begin{array}{r}\text { Controls Distance to Atlantic Ports } \\
\text { Controls City size in } 1300\end{array}$} & reported & Y & $\mathrm{Y}$ & Y & Y \\
\hline & Y & Y & Y & $\mathrm{Y}$ & $\mathrm{Y}$ \\
\hline \multirow{2}{*}{$\begin{array}{r}\text { Observations } \\
\text { R-squared }\end{array}$} & 1876 & 1876 & 1876 & 1876 & 1876 \\
\hline & 0.694 & 0.702 & 0.703 & 0.695 & 0.696 \\
\hline Number of cityid & 272 & 272 & 272 & 272 & 272 \\
\hline $\mathrm{p}$-value for joint significance Protestant & 0.000 & 0.047 & 0.006 & 0.014 & 0.058 \\
\hline p-value for joint significance triple interactions & 0.003 & 0.000 & 0.0116 & 0.472 & 0.508 \\
\hline
\end{tabular}

*: Significant at $10 \% ;{ }^{* *}: 5 \% ;{ }^{* * *}: 1 \%$. All regressions contain a full set of city and year fixed effects. P-values refer to a joint test significance of all coefficients relating to the post-Reformation period (interactions of respective variable with year dummies, 1600 and onwards). Robust standard errors, clustered by territory, in brackets. 